\title{
The Liquid Hand-to-Mouth: Evidence from a Personal Finance Management Software
}

\author{
Michaela Pagel* and Arna Vardardottir ${ }^{\dagger}$ \\ Columbia Business School \\ Copenhagen Business School
}

February 14, 2016

\begin{abstract}
We use a very accurate panel of all individual spending, income, balances, and credit limits from a financial aggregation app and document significant payday responses of spending to the arrival of both regular and irregular income. These payday responses are clean, robust, and homogeneous for all income and spending categories throughout the income distribution. Spending responses to income are typically explained by households' capital structures: households that hold little or no liquid wealth have to consume hand-tomouth. However, we find that few individuals hold little or no liquidity and also document that liquidity holdings are much larger than predicted by state-of-the-art models explaining spending responses with liquidity constraints due to illiquid savings. Given that present liquidity constraints do not bind, we analyze whether individuals hold cash cushions to cope with future liquidity constraints. To that end, we analyze cash holding responses to income payments inspired by the corporate finance literature. However, we find that individuals' cash responses are consistent with standard models without illiquid savings and neither present nor future liquidity constraints being frequently binding. Because these models are inconsistent with payday responses, we feel that the evidence suggests the existence of households that spend heuristically and call those the "liquid hand-to-mouth." JEL Codes: E03, D03, D91, D14.
\end{abstract}

\footnotetext{
*Division of Economics and Finance, Columbia Business School, New York, USA. mpagel@columbia.edu

†Department of Finance, Copenhagen Business School, 2000 Frederiksberg, Denmark. av.fi@cbs.dk We thank Steffen Anderssen, Jonathan Parker, Dan Silverman, Steve Zeldes, Wei Jiang, Emir Kamenica, Adam Szeidl, Matthew Rabin, Sumit Agarwal, and Paul Tetlock for their insightful comments. We also thank seminar participants at the University of British Columbia, University of Zurich, Carnegie Mellon University, Columbia University, CEPR in Gerzensee, Goethe University Frankfurt, and University of Lugano for all the constructive questions and remarks as well as Nathen Huang and Guangyu Wang for excellent research assistance. We are indebted to Ágúst Schweitz Eriksson and Meniga for providing and helping with the data. An earlier draft of this paper was circulating under the title "The Only Day Better than Friday is Payday!"
} 


\section{Introduction}

Standard economic theory states that consumption should not respond to the timing of predictable changes in disposable income. ${ }^{1}$ However, since Flavin (1981), a number of empirical studies document at both the micro and macro levels that consumption responds to disposable income, or that it is "excessively sensitive" to income. ${ }^{2}$ This excess sensitivity and the mechanisms behind it are important for understanding the effectiveness of short-term stimulus payments among other policy prescriptions. Recent advances in the consumption literature explain excess sensitivity via households' capital structures: in the presence of illiquid savings, many households consume hand-to-mouth because they hold little or no liquid wealth (Kaplan and Violante, 2014b; Laibson et al., 2015). Using very accurate data on spending, income, balances, and credit limits, this paper shows that 1) spending is excessively sensitive to income payments for at least half the population, 2) less than 3 percent of individuals have less than one day of spending left in liquidity before their paychecks, and 3) liquidity holdings are at least three times larger than predicted by these state-of-the-art economic models. Because current liquidity constraints are not binding, we then analyze whether cash holding responses indicate the presence of insufficient cash cushions and future liquidity constraints inspired by the cash-flow sensitivity of cash work in the corporate finance literature (Almeida et al., 2004). However, we find that individuals' cash holding responses do not indicate the presence of insufficient cash cushions and future liquidity constraints.

Our findings thus suggest that many households consume hand-to-mouth despite not being liquidity constrained in the present or future. Campbell and Mankiw (1989) are the first to assume that a fraction of income goes to hand-to-mouth consumers (who consume part of their disposable income each period) whereas the remainder goes to consumers who optimize intertemporally. Several papers since study the implications of including hand-to-mouth con-

\footnotetext{
${ }^{1}$ This is true for both the standard consumption-savings model (Friedman, 1957; Hall, 1978) and the more recent "buffer-stock" versions (Deaton, 1991; Carroll, 1997).

${ }^{2}$ Examples of micro evidence on excess sensitivity are Parker (1999), Souleles (1999), Shapiro and Slemrod (2003a), Shapiro and Slemrod (2003b), Shapiro and Slemrod (2009), Johnson et al. (2006), Parker et al. (2013), and Broda and Parker (2014) as surveyed in Jappelli and Pistaferri (2010) or Fuchs-Schundeln and Hassan (2015). Macro evidence is provided by Campbell and Mankiw $(1989,1990)$ in response to the seminal paper by Flavin (1981).
} 
sumers on the effects of monetary and fiscal policy in macroeconomic models. However, Kaplan and Violante (2014b) argue that measurements of hand-to-mouth behavior using balance sheets are misleading, because they focus on poor hand-to-mouth households and miss the "wealthy hand-to-mouth"-households who hold sizable amounts of wealth in illiquid assets, despite having very little to no liquid wealth. In addition to the poor and wealthy hand-tomouth, this paper suggests that there exists another class of households, the liquid hand-tomouth, who indeed consume heuristically rather than optimize intertemporally.

In contrast to the standard economic model, but aligned with previous studies, we start by documenting significant responses of spending to the arrival of both regular and irregular income. These payday responses are clean, robust, and homogeneous for all income and spending categories throughout the income distribution. Such hand-to-mouth behavior is predominantly explained by liquidity constraints. However, we find that almost all households spend when income becomes available-independent of whether or not they are liquidity constrained. Our measures of liquidity constraints include income, balances, credit limits, and whether or not households spend on (discretionary) goods and services right before and at the income arrival. However, we conclude that the fraction of constrained households is too small to quantitatively generate the degree of excess sensitivity documented empirically and also find that liquidity holdings are too large to generate high marginal propensities to consume out of fiscal stimulus paymens in the models by Kaplan and Violante (2014b) and Laibson et al. (2015).

These findings could be explained by our measure of liquidity constraints not capturing whether or not households actually feel liquidity constrained. More specifically, the classic measurement of liquidity constraints via balances and credit limits faces difficulties if households hold cash or credit cushions either to cope with unforeseen expenses or to term-save for foreseen expenses. Such insufficient cash cushions and potentially binding future liquidity constraints could explain payday responses, even when present liquidity constraints are not binding. To address this conjecture, we look at cash holding responses to income payments for different measures of liquidity constraints inspired by Almeida et al. (2004)-a highly-cited paper in the corporate finance literature proposing to look at cash, rather than investment sen- 
sitivities to cash inflows. If individuals are worried about binding liquidity constraints in the future and hold insufficient cash cushions, they have a high propensity to hold on to the cash upon receiving income payments. We thus compare the empirical patterns of individuals' cash holding responses with the predictions of three models: 1) a standard model in which individuals hold their lifetime savings in cash such that the marginal propensity to hold on to cash is simply the reverse of the marginal propensity to consume, 2) a model with liquid and illiquid savings in which individuals optimally hold little or no cash, and 3) a model with liquid and illiquid savings in which future liquidity constraints bind frequently. The third model predicts a decreasing relationship between cash holding responses and liquidity thus capturing insufficient cash cushions. However, we find that individuals' cash holding responses to income payments are in line with the first standard model that cannot explain high marginal propensities to consume. Thus, we conclude that neither current nor future liquidity constraints seem to explain payday responses. In our minds the prevalence of payday responses in the population points towards a different theoretical explanation. We theorize, that households consume heuristically and feel they have a license to spend upon income arrivals.

We follow Gelman et al. (2014), Baker (2013), Kuchler (2015), and Kueng (2015) by using data from a financial aggregation and service application (app), which overcomes the limitations of accuracy, scope, and frequency that existing data sources of consumption and income have. Gelman et al. (2014) were the first to advance the measurement of income and spending with this high-frequency app data derived from the actual transactions and account balances of individuals. Gelman et al. (2014) provide evidence on excess sensitivity by finding that there is a spending response to the arrival of anticipated income. Individuals' total spending rises substantially above average daily spending on the day that income arrives. However, the authors find that this excess sensitivity of spending results largely from the coincident timing of regular income and regular spending, while the remaining excess sensitivity is concentrated among individuals who are likely to be liquidity constrained. The authors consider total spending, nonrecurring spending, and spending on fast food and coffee shops in response to the arrival of regular paychecks or Social Security payments. Because our data stems from Iceland, it is 
particularly well suited for drawing a more precise picture of both regular and irregular income and many spending categories for three reasons. We 1) have access to income and spending data that are pre-categorized (and Iceland is a small country which makes accurate categorization easy), 2) use an app that is marketed through banks and supplied for their customers (thus covering a fairly broad fraction of the population), and 3) basically eliminate the one remaining limitation of using app data-the absence of cash transactions (in Iceland, consumers use electronic means of payments almost exclusively). Thus, our data is of exceptional thoroughness with respect to capturing all spending even in comparison to data sets of the same kind.

We apply the identification strategy from Gelman et al. (2014) to our income and spending panel data to measure the marginal propensity to consume out of income shocks, but, unlike Gelman et al. (2014), we do not conclude that excess sensitivity is limited to liquidityconstrained individuals or non-coffee-shop spending. First, we observe much cleaner and more homogeneous spending responses than Gelman et al. (2014) for ten income deciles and every income and spending category. When we split the sample into income deciles, we observe a monotonic decrease in the initial spending response from 80 percent to 25 percent above average daily spending. However, we fail to observe payday responses less than 25 percent even when splitting the sample in many other ways. We analyze heterogeneity by running regressions at the individual level and find that only 20 percent of the population display payday responses between zero and 20 percent while at least 50 percent of the population display payday responses of more than 20 percent. Second, we observe robust spending responses for consumers that are not liquidity-constrained by our measures. Again, we fail to observe payday responses less than 25 percent even for the most liquid individuals. To ensure that we do not pick up the coincident timing of consumption commitments and income explained in Gelman et al. (2014), we generally limit our spending measures to non-recurring spending. We also examine non-recurring and discretionary spending categories (such as restaurants and alcohol), perform our analyses on those whose income timings do not coincide with typical patterns, and look at irregular income categories (like tax rebates) to confirm our previous findings. ${ }^{3}$

\footnotetext{
${ }^{3}$ We have the following regular income categories: child support, benefits, child benefits, interest income, invalidity benefits, parental leave, pension, housing benefits, rental benefits, rental income, salary, student loans, and
} 
A natural question arises regarding the economic importance of understanding these payday responses. After all, calculations by Browning and Crossle (2001) show that, in a plausibly parameterized life-cycle buffer stock model, the utility loss from setting consumption equal to income (instead of fully optimizing) is second order. Cochrane (1989) and Krusell and Smith (1996) perform similar calculations in a representative agent environment. However, we think that payday effects are important for five reasons. First, we document such clean and homogeneous payday responses throughout a population holding substantial liquidity that they appear to point towards a shortcoming of the way we currently model economic behavior in a lifecycle consumption context. It appears as if individuals do not intertemporally optimize but, instead, use heuristics to decide how much to consume and save. In this paper, we remain agnostic about which assumptions about preferences drive hand-to-mouth behavior and we assume it could be caused by any cognitive, computational, or time limits of the household and that it may simply be a rule of thumb. However, we believe that our results raise an important issue: the lack of rigorous, portable, and generally-applicable models of such behavior. An early example of such a theory is Campbell and Mankiw (1989) who simply assume that a fraction of income goes to hand-to-mouth consumers who consume part of their disposable income each period. Beyond such an approach, the only existing theory rationalizing our findings is modeled in Delikouras and Korniotis (2014), who assume that individuals' marginal utility of consumption increases upon income arrivals because they feel they have a license to spend. Second, the analysis of individuals' cash holdings is important, as cash holdings have high opportunity costs if individuals were to invest their cash into the stock market. We assess whether individuals hold cash cushions to cope with future liquidity constraints; however, we find that neither present nor future liquidity constraints appear to matter, which implies that individuals forgo a considerable amount of return on their wealth by holding cash. Thus, this evidence suggests that the need for cash cushions does not bring about non-participation in the stock market.

unemployment benefits. And we have the following irregular income categories: damages, grant, other income, insurance claims, investment transactions, reimbursements, tax rebates, and travel allowances. The spending categories are groceries, fuel, alcohol, ready made food, home improvement, transportation, clothing and accessories, sports and activities, and pharmacies. We can observe expenditures on alcohol that is not bought at bars and restaurants because a state-owned company, State Alcohol and Tobacco Company, has a monopoly on the sale of alcoholic beverages in Iceland. 
Third, for countercyclical fiscal policy, it is important not only to know the rate at which fiscal stimulus payments are consumed by households but to also understand the mechanisms behind the effectiveness of tax rebates as a short-term stimulus for aggregate consumption. A collective body of evidence has convincingly concluded that households spend between 20 and 40 percent of rebates on nondurables in the quarter that they are received. Kaplan and Violante (2014b) offer a quantitative study of these episodes within a structural, dynamic, and forwardlooking model. In line with Kaplan and Violante (2014b), we find hand-to-mouth behavior to be pervasive throughout income classes. Unlike Kaplan and Violante (2014b), however, we find that only very few hand-to-mouth consumers are liquidity constrained, as measured by their liquid wealth. Additionally, we do not find the patterns in cash responses predicted by a model with illiquid savings. Finally, we confirm the finding by Parker (2014) that liquidity appears to be a very persistent household trait rather than the product of swings due to transitory income shocks, as predicted in the Kaplan and Violante (2014b) model. Fourth, payday responses are potentially important, because a monthly cycle in household expenditures could trigger a price-discriminating response by firms. Hastings and Washington (2010) use scanner data from the US and find that supermarkets have a procyclical pricing strategy: prices are high at the beginning of the month and low at the end. Fifth, we suggest caution regarding some policy prescriptions put forward in the existing literature. Parsons and van Wesep (2013), for example, argue that paychecks could be distributed more often to improve consumption smoothing and welfare. However, our results suggest that frequent disbursement may lead to overall higher consumption as partially found by Aguila et al. (2015).

The paper is organized as follows: first, we review the literature and provide some theoretical background in Section 2. Second, we briefly describe the data set and some summary statistics in Section 3. Third, we conduct the analysis in Section 4. Finally, Section 5 concludes the paper. 


\section{Literature Review and Theoretical Background}

Other empirical papers looking at expected temporary payments in order to test the permanent income hypothesis include Shapiro and Slemrod (1995), who conduct a phone survey in which 43 percent of respondents reported mostly spending a perfectly temporary income shock due to a reduction in tax withholding. The authors conclude that such spending is driven by a fraction of people following a simple rule to spend their current paychecks rather than by liquidity constraints. Shapiro and Slemrod (2003a) use a similar survey to investigate the effect of the income tax rebate of 2001, finding that 22 percent reported that they would mostly spend it thus supporting the existence of hand-to-mouth consumers. Parker (1999) examines whether or not spending changes when take-home pay increases in those months after wage earners hit the earnings ceiling for Social Security payroll taxes, and concludes that hand-to-mouth behavior is the more likely explanation for the correlation between consumption and takehome pay than liquidity constraints. However, these studies on the share of hand-to-mouth consumers are based on surveys that make it difficult to "follow the money" of consumers, since respondents may have little incentive to answer the questions accurately, not understand the wording of the questions properly, or behave differently in practice and forget their reported behavior. Moreover, such measurement error or noise in the data generated by surveys that simply ask about past purchases can increase with the length of the recall period (de Nicola and Giné, 2014). Additionally, surveys can produce biased - rather than merely noisy data if respondents have justification bias, concerns about surveyors sharing information, or stigma about their consumption habits (Karlan and Zinman, 2008).

Previous work on payday effects restricted attention to subpopulations. These papers document that expenditures and the caloric intake of poor households increase sharply at payday (e.g., Stephens, fthc; Huffman and Barenstein, 2005; Shapiro, 2005). More specifically, Stephens (fthc) and Mastrobuoni and Weinberg (2009) find that both consumption expenditures and consumption are higher in the week after Social Security checks are distributed, compared to the week before. Mastrobuoni and Weinberg (2009) propose hyperbolic discounting 
as an explanation for households with few or no assets. In the context of food stamps Shapiro (2005) also rejects the exponential discounting model by showing that food stamp recipients consume 10 to 15 percent fewer calories the week before food stamps are disbursed. Stephens and Unayama (2011) exploit an exogenous change in the frequency of pension payments in Japan when holding total pension income constant. Public pension benefits were paid out every three months before the change, and once every two months after. They find that, after the change, elderly households are better able to smooth consumption expenditures. However, Vellekoop (2013) shows that more frequent disbursements of checks could back-fire, as the payment of consumption commitments plays a role for disposable liquidity. Additionally, there exists evidence of intra-monthly cycles in financial crimes (Foley, 2011) and mortality (Evans and Moore, 2012). With respect to behavior and cognitive function around paydays, Carvalho et al. (fthc) fail to find before-after payday differences in risk-taking, the quality of decision-making, the performance in cognitive function tasks, or in heuristic judgments.

As pointed out by Kaplan and Violante (2014b), measurements of hand-to-mouth behavior based on households with near zero net worth may be misleading, because they miss wealthy individuals who engage in hand-to-mouth behavior due to illiquid wealth (such as housing or retirement accounts) and thus hold little to no liquid wealth despite substantial net worth. As a result, they consume all of their disposable income every period. As a theoretical starting point, one should thus use a model featuring two assets, one liquid and one illiquid. Recent theoretical examples of these two-asset environments are the ones seen in Angeletos et al. (2001), Laibson et al. (2003), Flavin and Nakagawa (2008), Chetty and Szeidl (2007), Alvarez et al. (2012), Huntley and Michelangeli (2014), and Kaplan and Violante (2014a). Angeletos et al. (2001) and Laibson et al. (2003) show that households with hyperbolic-discounting preferences optimally decide to lock their wealth in the illiquid asset in order to cope with selfcontrol problems that often strike during favorable temporary income shocks, which leads to a high marginal propensity to consume out of income. Other models generating such self-control problems are Bucciol (2012) and Pagel (2013). Moreover, Flavin and Nakagawa (2008) define a utility function over two consumption goods - one representing non-durable consumption and 
one representing housing, which is characterized by adjustment costs. As the utility function depends non-separably on the two goods, non-durable consumption is excessively sensitive. A similar utility function is assumed by Chetty and Szeidl (2007); however, this function is separable in the two goods, which implies that consumption is excessively sensitive with respect to the durable good only. Kaplan and Violante (2014a) do not need to assume that households have hyperbolic-discounting preferences and still generate a high marginal propensity to consume out of transitory shocks in a two-asset environment. The authors differentiate among three types of households: standard households, poor hand-to-mouth households holding little to no liquid and illiquid wealth, and wealthy hand-to-mouth households holding little to no liquid wealth but having significant amounts of illiquid assets on their balance sheets. Just like the poor households, wealthy hand-to-mouth households have large marginal propensities to consume out of small transitory income fluctuations. In a one-asset environment, Koszegi and Rabin (2009) show that, in an environment with little to no uncertainty, agents with referencedependent preferences may consume entire windfall gains. Moreover, Reis (2006) assumes that agents face costs when processing information and thus optimally decide to update their consumption plans sporadically, resulting in excessively smooth consumption that is shown to matter in the aggregate by Gabaix and Laibson (2002). Additionally, Tutoni (2010) assumes that consumers are rationally inattentive, and Attanasio and Pavoni (2011) show that excessively smooth consumption results from incomplete consumption insurance due to a moral hazard problem. Moreover, recent papers test the permanent income hypothesis using data from the labor market. Card et al. (2006) estimate the excess sensitivity of job search behavior to cash-on-hand, and Basten et al. (2014) examine the effect of severance payments on nonemployment duration. Dupas et al. (2015) find that bicycle taxi drivers in Western Kenya work more in response to cash needs. 


\section{Data and summary statistics}

\subsection{Data}

This paper exploits new data from Iceland generated by Meniga, a financial aggregation software provider to European banks and financial institutions. Meniga has become Europe's leading private financial management (PFM) provider. Its PFM solution is currently used in 13 countries, and more countries are already scheduled to be added in partnership with retail banks and financial institutions around the world.

Meniga's account aggregation platform allows bank customers to manage all their bank accounts and credit cards across multiple banks in one place by aggregating data from various sources (internal and external). Meniga's financial feed tells the story of consumers' financial lives as they unfold in familiar social media style. Categorized transactions are mixed in with automated and custom advice, notifications, messages, merchant funded offers, and various insights and interpretations of the users' finances. Figure 1 displays screenshots of the app's user interface. The first screenshot shows background characteristics that the user provides, the second one shows transactions, and the third one bank account information.

In October 2014, the Icelandic population counted 331,310 individuals. At the same time, one fourth of Icelandic households were using the Meniga app. Because the app is marketed through banks, the sample of Icelandic users is fairly representative. The company allows financial institutions to offer their online customers a platform to connect all their financial accounts, including bank and credit card accounts, to see all of them in a single location. Each day, the application automatically records all the bank and credit card transactions, including descriptions as well as balances, overdraft, and credit limits. We use the entire de-identified population of active users in Iceland and the data derived from their records from 2011 until 2015. We perform the analysis on normalized and aggregated user-level data for different income and spending categories. Additionally, the app collects demographic information such as age, gender, marital status, and postcode. Moreover, we can infer employment status, real estate ownership, and the presence of young children in the household from the data. Pre- 
sumably, the user population is not perfectly representative of the Icelandic population, but it is a substantial, heterogenous fraction that includes large numbers of users of different ages, education levels, and geographic locations.

\subsection{Summary statistics}

Table 1 displays summary statistics of the Icelandic users including not only income and spending in US dollars across four income quartiles, but also some demographic statistics. We can see that the average user is 40 years old, 15 percent of users are pensioners, 50 percent of users are female, 20 percent have children, and 8 percent are unemployed. For comparison, Statistics Iceland reports the average age in the population to be 37 years, 12 percent of Icelanders to be pensioners, 48 percent being female, 33 percent having children, and 6 percent being unemployed. Thus, our demographic statistics are remarkably similar to the overall Icelandic population. This is reassuring, seeing as a concern with using app data is that the user population is more likely to be young, well-situated, male, and tech-savvy relative to the overall population. The representative national household expenditure survey conducted by Statistics Iceland also reports income and spending statistics. In the table, parentheses indicate when spending categories did not match perfectly with the data. We can see that the income and spending figures are remarkably similar for those categories that match well. Figure 2 shows the distribution of regular income payments over the month. About 90 percent of the individuals in the sample get paid on a monthly basis whereas the remainder get paid on a more frequent basis.

\section{Analysis}

In this study, we estimate the share of hand-to-mouth consumers by running the following regression

$$
x_{i t}=\sum_{k=-7}^{7} \beta_{k} I_{i}\left(\text { Paid }_{t-k}\right)+\delta_{d o w}+\phi_{m}+\gamma_{y}+\eta_{i}+\epsilon_{i t}
$$


where $x_{i t}$ is the ratio of spending of individual $i$ to $i$ 's average daily spending at date $t, \delta_{\text {dow }}$ is a day-of-week fixed effect, $\phi_{m}$ is a month fixed effect, $\gamma_{y}$ is a year fixed effect, $\eta_{i}$ is an individual fixed effect, and $I_{i}\left(\operatorname{Paid}_{t-k}\right)$ is an indicator equal to 1 if $i$ received a payment at time $t-k$ and equal to 0 otherwise. The $\beta_{k}$ coefficients thus measure the fraction by which individual spending deviates from average daily spending in the days surrounding the arrival of a payment. The day-of-week dummies capture within-week patterns of both income and spending. We will initially differentiate between regular and irregular income arrivals and separate households into ten income deciles. We can also include day-of-month fixed effects as there is a lot of variation on which day individuals get paid as can be seen in Figure 2.

\subsection{Regular income arrival}

Figure 3 displays the consumption response to regular income payments of households in ten different income deciles as measured by their regular salary. It can be clearly seen that both poor and rich households respond to the arrival of their income, with the poorest households consuming 80 percent more than they would on an average day and the richest households spending 25 percent more. Even for the richest households, we observe a surprisingly high consumption response. Tables 2 and 3 present all regression results for four income quartiles and four types of spending. While grocery and fuel spending can be viewed as necessary, ready-made food (such as restaurants) and alcohol spending can be viewed as discretionary. Moreover, Figures 5 and 6 display the spending response to income of necessary categories and discretionary categories separately. As we can see, individuals are equally inclined to spend on necessary, as well as discretionary, goods and services, upon income arrivals. Unlike for tax rebates, there is no change in permanent income on pay dates, and furthermore there is no new information since paydays are perfectly predictable. While a buffer stock model can potentially explain sensitivity to tax rebates, it cannot explain sensitivity to pay dates. Thus, these payday responses are inconsistent with standard models of consumption and savings. Even though we focus on irregular spending and control for day-of-the-week effects, this spending response to regular income might be brought about by the coincident timing of regular income and irregular 
spending. Therefore, we will now look at irregular income. As a quick reminder, regular income categories include child support, benefits, child benefits, interest income, invalidity benefits, parental leave, pension, housing benefits, rental benefits, rental income, salary, student loans, and unemployment benefits. And we have the following irregular income categories: damages, grant, other income, insurance claims, investment transactions, reimbursements, tax rebates, and travel allowances.

\subsection{Irregular income arrival}

Figure 4 displays the consumption response to irregular income payments of households in ten different income deciles, which are measured by their regular salary. Again we observe both poor and rich households responding to the arrival of income, while poor households spending responses are somewhat more pronounced. Again, even for rich households, the spending response on the first day is large and significant at approximately 25 percent. Thus, we do not observe that the bulk of the spending response to income or excess sensitivity of consumption is due to poor households or the coincident timing of regular income and spending, as put forth in Gelman et al. (2014). More generally, the payday responses appear to be considerably more clean and homogenous than those documented in Gelman et al. (2014).

\subsection{Robustness}

We failed to find any income or spending category for which the payday responses are absent or even look at all different. Moreover, we could not imagine a mechanical reason for their presence. Because the irregular income responses may be unanticipated, payday responses are not necessarily inconsistent with the standard model. Nevertheless, confirming the existence of payday responses for irregular income rules out many alternative explanations for the payday responses to regular income such as naturally recurring spending and income, coordination stories that would not be picked up by the day-of-week fixed effects, or responses to firm pricing patterns. Additionally, we perform a number of robustness checks. First, we take a 
closer look at the characteristics of the individuals in the lowest income decile, because their spending response looks slightly different from the other income deciles. However, we do not observe unusual characteristics. Their mean income is around 750 dollars and mean age is 34 years, while the second decile's mean income and age are around 1000 dollars and 34 years, respectively. Second, we look at responses of the ready-made-food category, since it is instantly consumed and aligns spending with consumption. Third, we only look at individuals who are paid on unusual days. When doing so, we also ensure that we observe payday responses for all categories and not only categories such as restaurants and alcohol that are likely to be consumed alongside coworkers being paid on the same unusual paydays. Fourth, we include day-of-the-month fixed effects on top of day-of-the-week and year-month fixed effects. Fifth, we look only at tax rebates and lottery winnings to control for potential endogeneity of income. Sixth, we look at individuals with and without spousal linkages to ensure that responses are not driven by intra-household bargaining. Seventh, any price-discrimanatory response of firms would not explain the magnitude of the observed effects (Hastings and Washington (2010)) and not apply to individuals with unusual paydays or irregular income. Overall, we conclude that spending responses to income arrivals are a very robust phenomenon that is cleanly estimated and prevalent throughout the population. Given the robustness of these payday responses, we think trying to better understand what is driving them is a valuable exercise.

\subsection{Heterogeneity}

We are interested in the question of whether the payday responses are prevalent for a large fraction of the population rather than being driven by a small fraction of the population while a large fraction of the population does not display payday responses. To do so we run a regression for each individual in four income and salary quartiles and display their individual payday coefficients in Figure 7. It can be seen that around 22 percent of individuals have a payday coefficient equal to zero. Then, there is some negative coefficient mass but more positive coefficient mass which results in an average coefficient of around 0.8 for the lowest quartile and 0.25 for the highest quartile. It can thus be seen that at least half the population displays 
substantial payday responses rather than a small fraction of the population.

\subsection{Internal versus external margin of spending}

We are interested in the question of whether the payday responses are an internal or external phenomenon in the sense of individuals spending more when they go shopping or making an additional shopping trip. In Table 4 we display the results of regressions that estimate how much more likely individuals are to buy different categories, such as groceries, fuel, and restaurants, on their payday. For instance, individuals are 11 percent more likely to go on any shopping trip on paydays. In a second set of regressions, we then compare how much they spend on the categories if they shop on payday and if they shop on any other day. Here it can be seen that individuals spend 21 dollar more on all shopping trips on their paydays. Because individuals spend on average 50 dollars every day on non-recurring consumption and around 80 dollars on paydays, this 20 dollar increase corresponds to around 60 percent of the increase in spending on paydays. Thus, individuals are both more likely to go shopping and if they go shopping, they spend more than they would on a shopping day when they do not get paid.

\subsection{Taking a closer look at liquidity constraints}

Thus far, our results suggest that hand-to-mouth behavior is prevalent across all income groups, which casts doubt that liquidity constraints are the only explanation. To further establish that liquidity-constrained households are not alone in exhibiting spending responses, we now look at different measures of liquidity constraints: cash holdings in checking and savings accounts, cash holdings in checking and savings accounts plus credit card balances plus credit limits and overdraft limits, credit utilization, and spending on (discretionary) goods and services right before income arrives. All liquidity measures are normalized by the average consumption of each individual. Figures 8 to 10 compare the spending responses to regular and irregular income for three terciles of our standard measures of liquidity: cash, cash and credit lines, and credit utilization. Figures 11 and 12 compare the spending responses to regular and irregular income 
for three terciles of our new measures of liquidity: whether individuals spend on (discretionary) goods and services prior to the income arrivals. Overall we see that households exhibit spending responses, even in the highest tercile of all liquidity measures.

Furthermore, we look at the distribution of cash holdings - that is, checking and savings accounts balances plus credit card balances - and liquidity - that is, overdraft and credit limits plus checking and savings accounts balances plus credit card balances - before paydays in Figure 13. We see that cash holdings fall discontinually at zero when overdrafts start to cost interest, and about 12 percent of individuals hold fewer than ten days of cash in their checking and savings accounts. Moreover, about 11 percent of individuals hold fewer than ten consumption days of liquidity. In turn, Figure 14 provides a breakdown by 1 to 10 days of spending for cash and liquidity for the individuals holding less than 10 days of cash or liquidity respectively. Here we see that less than 3 percent of individuals hold less than one day of spending in liquidity and less than 4 percent hold less than one day of spending in cash. Thus, by our measures, the fraction of liquidity-constrained individuals is quantitatively too small to explain the degree of spending response to income, and so we conclude that liquidity constraints in the classical sense are unlikely to be an explanation for payday responses.

Additionally, Table 5 displays summary statistics for the three terciles of liquidity in consumption days. We can see that even the most liquidity-constrained households hold considerable liquidity of approximately 38 days of spending, while the least liquidity-constrained tercile of individuals hold approximately 546 days of spending in liquidity. When we compare these numbers to a state-of-the-art model developed by Kaplan and Violante (2014b) to explain high marginal propensities to consume out of tax rebates, we see a discrepancy between the theoretical predictions and the empirical evidence of how much liquid assets individuals hold. Figure 15 shows the life-cycle profiles of liquidity normalized by quarterly consumption for five quintiles of the distribution of agents in the model of Kaplan and Violante (2014b). We see that liquid asset holdings of the bottom three quintiles are basically zero for all the simulated agents' lives. The top two quintiles of agents hold approximately 4 quarters of consumption in liquidity on average. In contrast, empirically, the most liquid tercile of individuals hold 
6.1 quarters of consumption in liquidity on average, while the middle and least liquid terciles hold 1.37 and 0.41 quarters of consumption in liquidity - all of which far exceeds the predictions of the model. Moreover, if the Kaplan and Violante (2014b) model is forced to generate the amount of liquidity we observe in the data the fixed costs of the illiquid asset have to be very low which implies that individuals can adjust their illiquid asset holdings easily and that reduces their marginal propensity to consume out of fiscal stimulus payments.

Overall, the literature examining liquidity constraints is very mixed. Shapiro and Slemrod (2009) document that poor households - arguably more likely to be liquidity constrained - did not spend most of the 2008 tax rebate as the fiscal stimulus package intended. In contrast to policy makers' expectations, these households ended up using the funds to pay off debt, which corresponds to cash hoarding that relieves current and future liquidity constraints. In contrast, Shapiro and Slemrod (1995) find that those expecting their financial conditions to be worse in the next year were more likely to spend the 1992 change in tax withholding. With respect to current financial conditions, the authors cannot document a stable relationship with the propensity to spend. Moreover, the authors find that households that typically get a refund were more likely to spend the extra take-home pay; while this finding is consistent with theories of inertia, lack of foresight, or failure to optimize, it is not aligned with liquidity constraints. Overall, the authors conclude that liquidity constraints do not motivate the spending behavior of the 43 percent of households who report that the timing of tax payments would affect their consumption. Souleles (1999) looks at the consumption responses in non-durable and durable consumption, in addition to documenting the advantages of using tax refunds to document excess sensitivity in consumption. While the author finds that constrained households are more likely to spend their tax refunds on non-durable consumption, the picture is reversed for durable consumption. Thus, liquidity-unconstrained households are not overwithholding to force themselves to save up enough for durable consumption goods because they could have easily undone any forced saving by drawing down their liquid assets.

These results suggest that liquidity constraints may not be straightforward to document empirically. While some households are liquidity constrained in the classical sense - that is, they 
live from paycheck to paycheck and have no savings - other households may hold a cash cushion for either unforeseen adverse expenditure shocks or foreseen expenses. However, they may still be liquidity constrained inasmuch that they would consume or invest more if they could borrow more cheaply. Abstracting from cash cushions, the theoretical literature has explicitly considered wealthy households to be liquidity constrained when they lock their wealth in illiquid assets (Laibson et al., 2003; Kaplan and Violante, 2014b). However, empirically, we find that almost all households hold large amounts of cash, though few hit a liquidity constraint of no savings before their paychecks. Because Kaplan and Violante (2014b) use Survey of Consumer Finances data, the authors do not observe liquidity holdings before paychecks but only average liquidity holdings. They classify individuals as hand-to-mouth consumers when their average liquid wealth is less than half of their earnings and find that this is the case for 30 percent of the US population. For comparison, using their definition we obtain that 58 percent of households are hand-to-mouth in our population. However, because individuals have sufficient liquidity at the end of their pay cycle, this cannot explain payday responses to income. To the extent that payday responses are driven by the same mechanism as responses to fiscal stimulus payments we thus rais an important question: how can we define liquidity-constrained individuals and identify them empirically?

\subsection{Looking at cash holding responses to income payments}

Given the difficulties of measuring liquidity constraints in the presence of cushions, we are interested in a different method that takes into account the potential existence of cash cushions. To this end, inspired by the corporate finance literature, we think about a measure of liquidity constraints derived from individuals' demands for liquidity. The methodology follows the one used in the influential paper by Almeida et al. (2004) titled, "The Cash Flow Sensitivity of Cash." In this paper, the authors develop a new test of the effect of financial constraints on corporate policies. This effect of financial constraints is captured by the firm's propensity to save cash out of cash inflows. The authors hypothesize that constrained firms should have a positive cash flow sensitivity of cash, while unconstrained firms' cash savings should not be 
systematically related to cash flows. In a household context, we empirically assess households' propensity to increase cash cushions after cash inflows and how this propensity is related to proxies for liquidity constraints. If a household is liquidity constrained and does not have access to credit, it will try to increase its cash cushion after cash inflows.

In corporate finance, the analysis of the effects of financial constraints on firm behavior and the manner in which firms perform financial management have a long tradition. The paper by Almeida et al. (2004) states that firms want to have a liquid balance sheet to undertake valuable projects when they arise. However, if a firm has unrestricted access to external capital - that is, if a firm is financially unconstrained - there is no need to safeguard against future investment needs and, so, corporate liquidity becomes irrelevant. In contrast, when the firm faces financing frictions, liquidity management is a key issue for corporate policy. Thus, a link between financial constraints and corporate liquidity demand exists, which has been ignored by the prior literature focused on corporate investment demand. In Fazzari et al. (1988)'s seminal paper, the authors propose that when firms face financing constraints, investment spending will vary with the availability of internal funds, rather than just with the availability of positive net present value (NPV) projects. Accordingly, the authors examine the influence of financing frictions on corporate investment by comparing the empirical sensitivity of investment to cash flow across groups of firms that are sorted according to a proxy for financial constraints. Follow-up research, however, has identified several problems with that strategy regarding the robustness of the implications theoretically and empirically. Moreover, if cash flows contain valuable information about a firm's investment opportunities, the cross-sectional patterns reported by Fazzari et al. (1988) can be consistent with a model with no financing frictions. Almeida et al. (2004) then advance the literature by examining the empirical cash flow sensitivities of cash, rather than the cash flow sensitivities of investment. In a household context, the study by Fazzari et al. (1988) may correspond to the analysis of household spending or investment in response to cash inflows. Households may spend or invest more in response to cash inflows because they are currently liquidity constrained. However, we find that individuals hold too much cash relative to the predictions on state-of-the-art economic models. In turn, we want to examine 
whether individuals payday responses are brought about by a concern about future liquidity constraints, which would be reflected in a high marginal propensity to hold on to cash.

To formalize these ideas, Figure 16 shows the marginal propensities to hold on to cash implied by three different simple models. First, we consider a standard consumption-savings model without illiquid savings. In this model, the marginal propensity to hold on to cash (MPCash) equals one minus the marginal propensity to consume (MPCons), i.e. MPCash = 1-MPCons, as the agent holds his entire life-time wealth in cash. Since the MPCons in this model is always decreasing in income or liquidity, the MPCash will always be increasing. Furthermore, the MPCash is higher when the agent's horizon increases, as he only consumes a small amount of his income and saves most of it. Second, we consider a consumption-savings model in which the agent can save in a liquid or an illiquid asset that pays slightly higher interest. In such a model, the MPCash may be either increasing or decreasing in liquidity or income. The reason for this is that the MPCash equals one minus the MPCons minus the marginal propensity to invest into the illiquid asset (MPIllInv), i.e., MPCash = 1-MPConsMPIllInv. While the MPCons is always decreasing in liquidity, the MPIllInv is increasing, which implies that the MPCash is either increasing or decreasing. It turns out that for most reasonable parameter combinations, the MPCash is increasing in income or liquidity. The intuition is that the agent wants to allocate consumption to today and the future periods when he becomes richer. This model is a simple version of the model in Kaplan and Violante (2014b). To obtain the result from the corporate finance literature - a MPCash that is decreasing in liquidity - one needs to introduce more frequently binding future liquidity constraints. In the two initial models, the agent expects future liquidity constraints and can easily ensure these do not bind for most income realizations. One way to increase the importance of future liquidity constraints is to assume that the agent receives news about income shocks in the future, but will not be able to consume that income immediately. In such a situation, the MPCash becomes decreasing in liquidity or income for many parameter combinations, as predicted in the corporate finance models.

Figure 17 displays individuals' cash holding responses to regular income payments and 
salary payments for three terciles of liquidity. We can see that less liquidity constrained individuals have larger cash holding responses than more liquidity-constrained individuals, as predicted by a standard consumption-savings model. Given that inert individuals hold on to cash automatically, we conclude that cash responses do not seem to indicate future liquidity constraints. All of these pictures show an increasing relationship between the propensity to hold on to cash and liquidity constraints, in addition to showing a very high propensity to hold on to cash much higher than the propensity to consume. These findings are consistent with the standard consumption-savings model without illiquid savings. This model, however, is not consistent with a high marginal propensity to consume out of transitory income shocks. In conclusion, this section looked at current and future liquidity constraints as a potential explanation for payday responses, but could only establish that neither current nor future liquidity constraints can account for the observed payday responses to income payments.

Individuals can change reduce overdraft limits relatively easily, while any credit limit increases have to be approved by the bank. Thus, we want to make sure that the increasing cash responses are not driven by changes in overdraft limits initiated by the individuals on paydays. Looking at changes in overdraft limits around paydays yields very interesting results. In Figure 19, it is evident that individuals with less liquidity tend to reduce their overdraft limits around paydays, while individuals with high liquidity do not engage in such behavior. Standard economic theory predicts that individuals should never reduce their limits, as borrowing opportunities are always weakly welfare increasing. However, we clearly see that individuals tend to reduce their limits after paydays. A potential explanation is that individuals want to restrict their future selves from borrowing or that they want to reduce their mental borrowing accounts. To ensure that the increasing payday liquidity responses documented are not brought about by the fact that low-liquidity individuals tend to reduce their limits after paydays, we also look at individuals' balances - that is, their current and savings account balance minus their credit balance - in Figure 20. We again observe high and increasing responses consistent with a model without illiquid savings or future binding liquidity constraints. 


\section{Conclusion}

We use data from a financial account app in Iceland, characterized by outstanding accuracy and comprehensiveness due to Icelanders' nearly exclusive use of electronic payments, to evaluate whether spending or consumption is the result of an intertemporal optimization problem and, therefore, independent of income. In line with previous studies and contradicting this theoretical prediction, we find significant responses of spending to the arrival of regular and irregular income on paydays. However, in contrast to previous studies, we argue that handto-mouth behavior is not limited to liquidity-constrained households by showing that nonliquidity-constrained households exhibit hand-to-mouth behavior through three measures of liquidity constraints: balances and credit limits, spending on discretionary goods and services, and spending right before the income arrival. Overall, less than 3 percent of individuals have fewer than one day of average spending left in liquidity before their paydays. Moreover, individuals' average cash holdings seem to be much larger than predicted by state-of-the-art economic models explaining high marginal propensities to consume out of transitory income shocks via illiquid savings. Because individuals may either hold cash cushions or term-save, we also look at cash holding responses to income payments inspired by the corporate finance literature and compare those to the predictions of models with and without illiquid savings and future binding liquidity constraints. Because the cash holding responses are most consistent with the standard consumption-savings problem without illiquid savings or future binding liquidity constraints, we argue that the evidence is not consistent with either present or future liquidity constraints. Instead, we argue that consumers may feel they have a license to spend upon income arrivals as modeled in Delikouras and Korniotis (2014). 


\section{References}

Aguila, E., Kapteyn, A., and Perez-Arce, F. Consumption Smoothing, Frequency of Benefit Payments, and Effectiveness of Social Programs. Working Paper, 2015.

Almeida, H., Campello, M., and Weisbach, M. The Cash Flow Sensitivity of Cash. Journal of Finance, 59(4):1777-1804, 2004.

Alvarez, F., Guiso, L., and Lippi, F. Durable Consumption and Asset Management with Transaction and Observation Costs. American Economic Review, 5(102):2272-2300, 2012.

Angeletos, G. M., Laibson, D., Repetto, A., and Weinberg, S. The Hyperbolic Consumption Model: Calibration, Simulation, and Empirical Evaluation. Journal of Economic Perspectives, 15(3):47, 2001.

Attanasio, . and Pavoni, N. Risk Sharing in Private Information Models with Asset Accumulation: Explaining the Excess Smoothness of Consumption. Econometrica, 79(4):1027-1068, 2011.

Baker, S. R. Debt and the Consumption Response to Household Income Shocks. Mimeo, 2013.

Basten, C., Fagereng, A., and Telle, K. Cash-on-hand and the Duration of Job Search: Quasiexperimental Evidence from Norway. Economic Journal, 124 (576):540-568, 2014.

Broda, C. and Parker, J. The Economic Stimulus Payments of 2008 and the Aggregate Demand for Consumption. Mimeo, 2014.

Browning, M. and Crossle, T. F. The Life-Cycle Model of Consumption and Saving. Journal of Economic Perspectives, 15(3):3-22, 2001.

Bucciol, A. Measuring Self-Control Problems: A Structural Estimation. Journal of the European Economic Association, 2012. 
Campbell, J. Y. and Mankiw, N. G. Consumption, Income and Interest Rates: Reinterpreting the Time Series Evidence. NBER Macroeconomics Annual 1989, Volume 4, NBER Chapters National Bureau of Economic Research, Inc., pages 185-246, 1989.

Campbell, J. Y. and Mankiw, N. G. Permanent Income, Current Income, and Consumption. Journal of Business and Economic Statistics, 8(3):265-279, 1990.

Card, D., Chetty, R., and Weber, A. Cash-on-Hand and Competing Models of Intertemporal Behavior: New Evidence from the Labor Market. NBER Working Paper No. 12639, 2006.

Carroll, C. D. Buffer Stock Saving and the Life Cycle/Permanent Income Hypothesis. Quarterly Journal of Economics, CXII:1-56, 1997.

Carvalho, L., Meier, S., and Wang, S. Poverty and Economic Decision-Making: Evidence from Changes in Financial Resources at Payday. American Economic Review, fthc.

Chetty, R. and Szeidl, A. Consumption Commitments and Risk Preferences. Quarterly Journal of Economics, 122(2):831-877, 2007.

Cochrane, J. H. The Sensitivity of Tests of the Intertemporal Allocation of Consumption to Near-Rational Alternatives. American Economic Review, 79(3):909-936, 1989.

de Nicola, F. and Giné, X. How accurate are recall data? evidence from coastal india. Journal of Development Economics, 106(0):52 - 65, 2014. ISSN 0304-3878. doi: http://dx.doi.org/10.1016/j.jdeveco.2013.08.008. URL http: //www . sciencedirect . com/ science/article/pii/S0304387813001235.

Deaton, A. Saving and Liquidity Constraints. Econometrica, 59:1221-1248, 1991.

Delikouras, S. and Korniotis, M. Working Paperl, 2014.

Dupas, P., Robinson, J., and Saavedra, S. The Daily Grind: Cash Needs, Labor Supply and Self-Control. Working Paper, 2015. 
Evans, W. N. and Moore, T. J. Liquidity, economic activity, and mortality. Review of Economics and Statistics, 94(2):400-418, 2014/04/02 2012. doi: 10.1162/REST $\{\backslash$ - $\}$ a $\{\backslash$ \}00184. URL http://dx.doi.org/10.1162/REST_a_00184.

Fazzari, S., Hubbard, G., and Petersen, B. Financing Constraints and Corporate Investment. Brookings Papers on Economic Activity, 1:141-206, 1988.

Flavin, M. The Adjustment of Consumption to Changing Expectations about Future Income. Journal of Political Economy, 89:974-1009, 1981.

Flavin, M. and Nakagawa, S. A Model of Housing in the Presence of Adjustment Costs: A Structural Interpretation of Habit Persistence. American Economic Review, 98(1):474-495, 2008.

Foley, C. F. Welfare payments and crime. Review of Economics and Statistics, 93(1):97-112, 2014/04/02 2011. doi: 10.1162/REST $\{\backslash-\} a\{\backslash$ \}00068. URL http://dx.doi.org/10. 1162/REST_a_00068.

Friedman, M. A Theory of the Consumption Function. Number frie57-1 in NBER Books. National Bureau of Economic Research, Inc, 1957. URL http://ideas.repec.org/b/ nbr/nberbk/frie57-1.html.

Fuchs-Schundeln, N. and Hassan, T. Natural Experiments in Macroeconomics. Working Paper, 2015.

Gabaix, X. and Laibson, D. The 6D Bias and the Equity-Premium Puzzle. NBER Macroeconomics Annual, 16:257-312, 2002.

Gelman, M., Kariv, S., Shapiro, M. D., Silverman, D., and Tadelis, S. Harnessing naturally occurring data to measure the response of spending to income. Science, 345(6193):212-215, 2014.

Hall, R. E. Stochastic Implications of the Life Cycle-Permanent Income Hypothesis: Theory and Evidence. Journal of Political Economy, 86(6):971-987, 1978. 
Hastings, J. and Washington, E. The first of the month effect: Consumer behavior and store responses. American Economic Journal: Economic Policy, 2(2):pp. 142-162, 2010. ISSN 19457731. URL http://www.jstor.org/stable/25760066.

Huffman, D. and Barenstein, M. A Monthly Struggle for Self-Control? Hyperbolic Discounting, Mental Accounting, and the Fall in Consumption Between Paydays. Working Paper IZA Bonn, 2005.

Huntley, J. and Michelangeli, V. Can Tax Rebates Stimulate Spending in a Life-Cycle Model? American Economic Journal: Macroeconomics, 1(6):162-189, 2014.

Jappelli, T. and Pistaferri, L. The Consumption Response to Income Changes. Annual Review of Economics, 2:479-506, 2010.

Johnson, D., Parker, J., and Souleles, N. Household Expenditure and the Income Tax Rebates of 2001. American Economic Review, 96(5):1598-1610, 2006.

Kaplan, G. and Violante, G. A Tale of Two Stimulus Payments: 2001 vs 2008. American Economic Review (Papers and Proceedings), 5(104):162-189, 2014a.

Kaplan, G. and Violante, G. A model of the consumption response to fiscal stimulus payments. Econometrica, 82:1199-1239, 2014b.

Karlan, D. and Zinman, J. Lying about borrowing. Journal of the European Economic Association, 6(2/3):pp. 510-521, 2008. ISSN 15424766. URL http://www . jstor.org/stable/ 40282660 .

Koszegi, B. and Rabin, M. Reference-Dependent Consumption Plans. American Economic Review, 99(3):909-936, 2009.

Krusell, P. and Smith, A. Rules of Thumb in Macroeconomic Equilibrium: A Quantitative Analysis. Journal of Economic Dynamics and Control, 20(4):527-558, 1996.

Kuchler, T. Sticking To Your Plan: Empirical Evidence on the Role of Present Bias for Credit Card Debt Paydown. Working Paper, 2015. 
Kueng, L. Explaining Consumption Excess Sensitivity with Near-Rationality: Evidence from Large Predetermined Payments. Working Paper, 2015.

Laibson, D., Repetto, A., and Tobacman, J. A Debt Puzzle. in Philippe Aghion, Roman Frydman, Joseph Stiglitz, and Michael Woodford, eds., Knowledge, Information, and Expectations in Modern Economics: In Honor of Edmund S. Phelps, Princeton: Princeton University Press, 2003.

Laibson, D., Repetto, A., and Tobacman, J. Estimating Discount Functions with Consumption Choices over the Lifecycle. Working Paper, 2015.

Mastrobuoni, G. and Weinberg, M. Heterogeneity in intra-monthly consumption patterns, selfcontrol, and savings at retirement. American Economic Journal.Economic Policy, 1(2):163189, 08 2009. URL http://search.proquest.com/docview/872053305?accountid= 39039.

Pagel, M. Expectations-based Reference-Dependent Life-Cycle Consumption. Mimeo, 2013.

Parker, J. A. The Reaction of Household Consumption to Predictable Changes in Social Security Taxes. American Economic Review, 89(4):959-973, 1999.

Parker, J. A. Why Don't Households Smooth Consumption? Evidence from a 25 million dollar experiment. Working Paper, 2014.

Parker, J. A., Souleles, N., Johnson, D., and McClelland, R. Consumer Spending and the Economic Stimulus Payments of 2008. American Economic Review, 103(6):2530-53, 2013.

Parsons, C. A. and van Wesep, E. D. The timing of pay. Journal of Financial Economics, 109 (2):373-397, 2013.

Reis, R. Inattentive Consumers. Journal of Monetary Economics, 53:1761-1800, 2006.

Shapiro, J. Is there a daily discount rate? Evidence from the food stamp nutrition cycle. Journal of Public Economics, (89):303-325, 2005. 
Shapiro, M. and Slemrod, J. Consumer Response to Tax Rebates. American Economic Review, 93(1):381-396, 2003a.

Shapiro, M. and Slemrod, J. Did the 2001 Tax Rebate Stimulate Spending? Evidence from Taxpayer Surveys. Tax Policy and the Economy, 17:83-109, $2003 \mathrm{~b}$.

Shapiro, M. and Slemrod, J. Did the 2008 Tax Rebates Stimulate Spending? American Economic Review, 99(2):374-379, 2009.

Shapiro, M. D. and Slemrod, J. Consumer response to the timing of income: Evidence from a change in tax withholding. American Economic Review, 85(1):274-83, March 1995. URL http://ideas.repec.org/a/aea/aecrev/v85y1995i1p274-83.html.

Souleles, N. The Response of Household Consumption to Income Tax Refunds. American Economic Review, 89(4):947-958, 1999.

Stephens, M. 3rd of Tha Month: Do Social Security Recipients Smooth Consumption Between Checks? American Economic Review, 93(1), fthc.

Stephens, M. and Unayama, T. The consumption response to seasonal income: Evidence from japanese public pension benefits. American Economic Journal: Applied Economics, 3(4):86-118, October 2011. URL http://ideas.repec.org/a/aea/aejapp/ v3y2011i4p86-118.html.

Tutoni, A. Rationally Inattentive Consumption Choices. Review of Economic Dynamics, 16: 421-439, 2010.

Vellekoop, N. Explaining intra-monthly consumption patterns: The timing of income or the timing of consumption commitments? Working paper, http://ssrn.com/abstract=2248641 or http://dx.doi.org/10.2139/ssrn.2248641, 2013. 


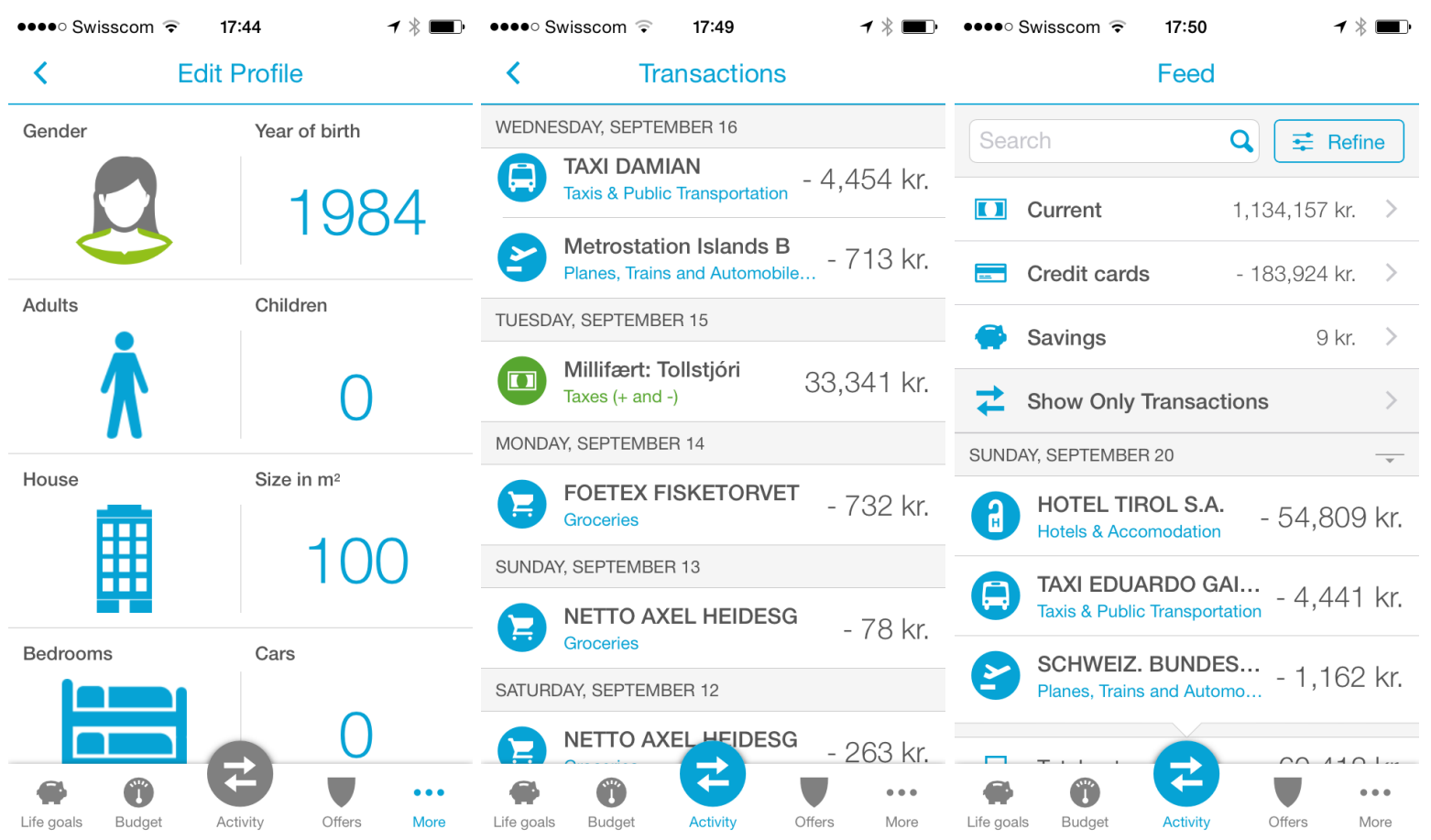

Figure 1: The financial aggregation app: screenshots 
Table 1: Summary Statistics

\begin{tabular}{lccc}
\hline \hline & Mean & $\begin{array}{c}\text { Standard } \\
\text { Deviation }\end{array}$ & $\begin{array}{c}\text { Statistics } \\
\text { Iceland }\end{array}$ \\
\hline Monthly total income & 3256.1 & 3530.5 & 4316 \\
Monthly regular income & 3038.2 & 3184.3 & 3227 \\
Monthly salary & 2703.5 & 2992.5 & 2456 \\
Monthly irregular income & 217.82 & 1414.8 & 1089 \\
Monthly spending: & & & \\
Total & 1315.1 & 1224.3 & \\
Groceries & 468.29 & 389.29 & 490 \\
Fuel & 235.88 & 258.77 & $(359)$ \\
$\quad$ Alcohol & 61.75 & 121.43 & 85 \\
Ready Made Food & 170.19 & 172.64 & $(252)$ \\
Home Improvement & 150.16 & 464.94 & $(229)$ \\
Transportations & 58.33 & 700.06 & 66 \\
Clothing and Accessories & 86.62 & 181.27 & 96 \\
Sports and Activities & 44.29 & 148.41 & $(36)$ \\
Pharmacies & 39.62 & 62.08 & 42 \\
Age & 40.6 & 11.5 & 37.2 \\
Female & 0.45 & 0.50 & 0.48 \\
Unemployed & 0.08 & 0.27 & 0.06 \\
Parent & 0.23 & 0.42 & 0.33 \\
Pensioner & 0.15 & 0.36 & 0.12 \\
& & & \\
\hline
\end{tabular}

Note: All numbers are in US dollars. Parentheses indicate that data categories do not match perfectly.

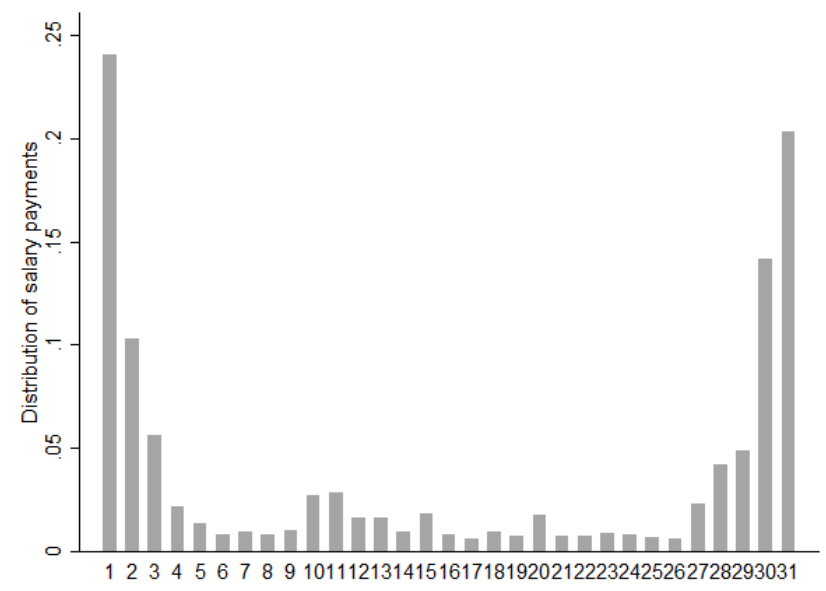

Figure 2: The Distribution of Paycheck Arrival on the Day of the Month 


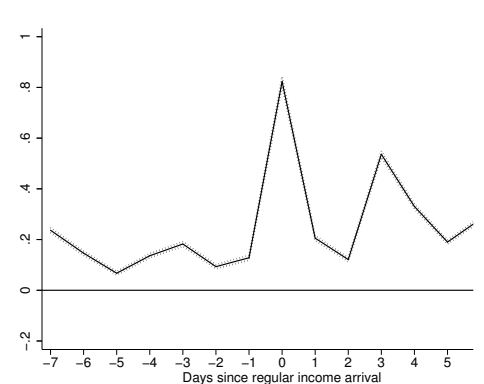

Salary Group 1

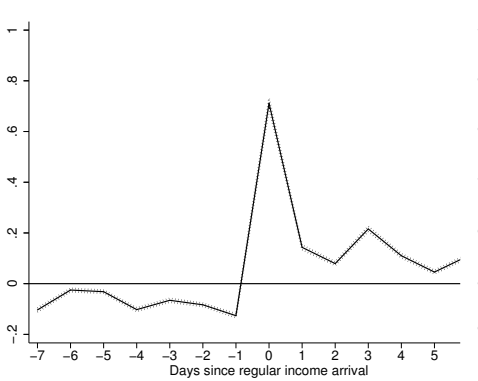

Salary Group 2

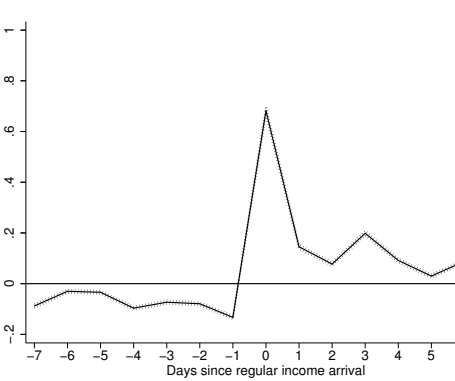

Salary Group 3

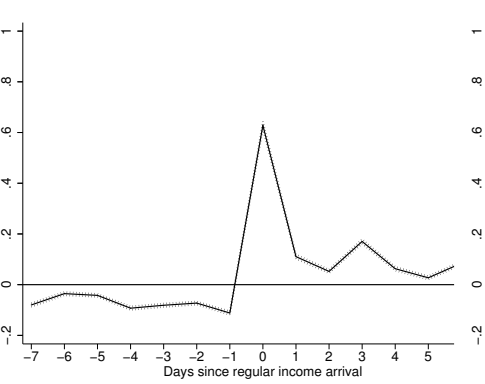

Salary Group 4

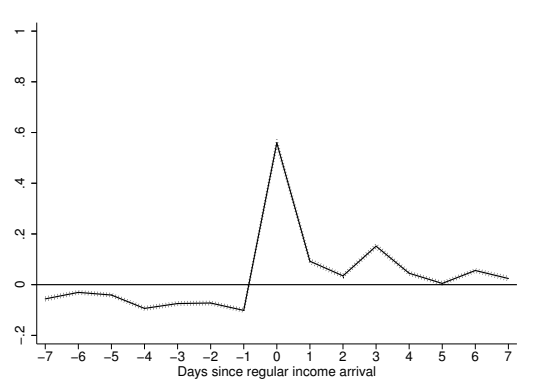

Salary Group 5

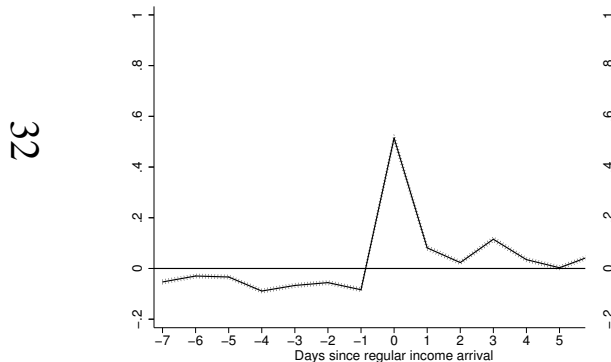

Salary Group 6

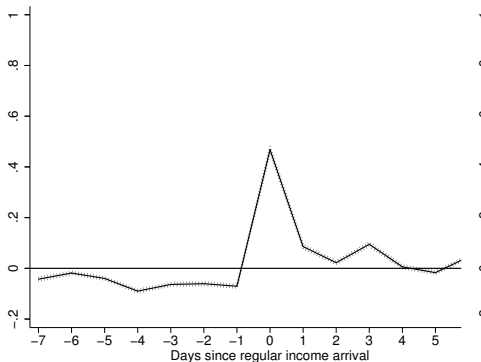

Salary Group 7

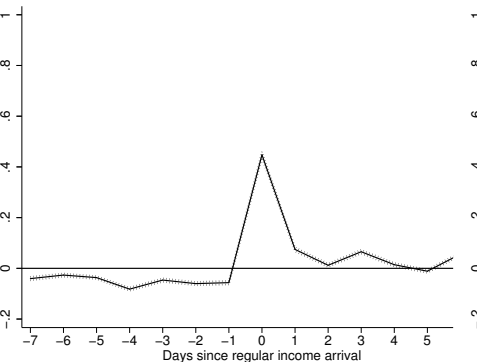

Salary Group 8

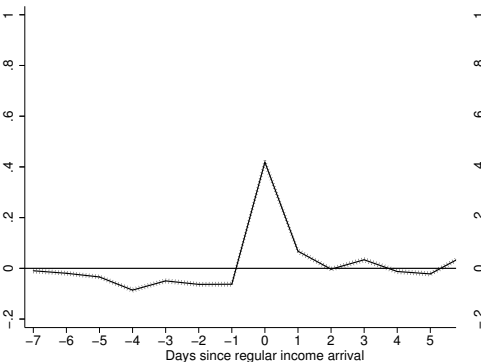

Salary Group 9

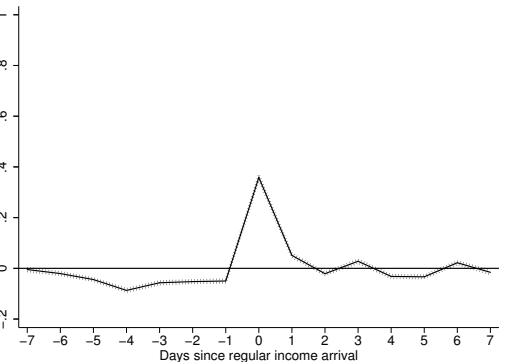

Salary Group 10

Figure 3: The Effects of Regular Income on Spending 


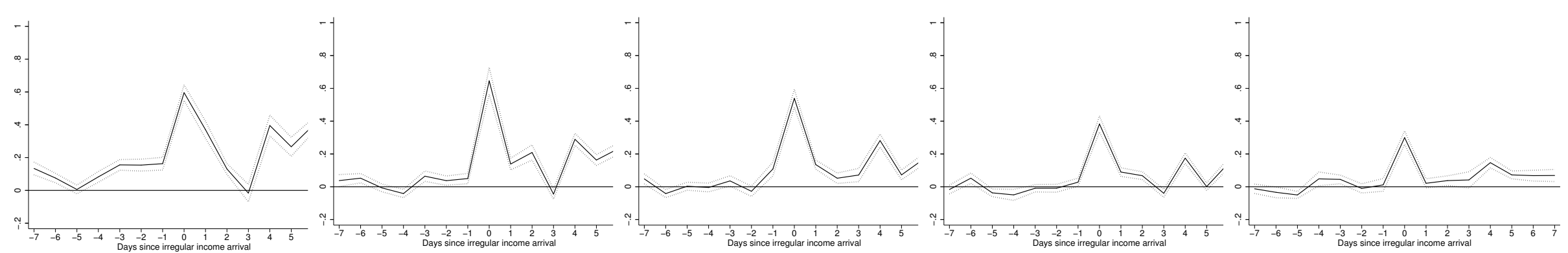

Salary Group 1

Salary Group 2

Salary Group 3

Salary Group 4

Salary Group 5

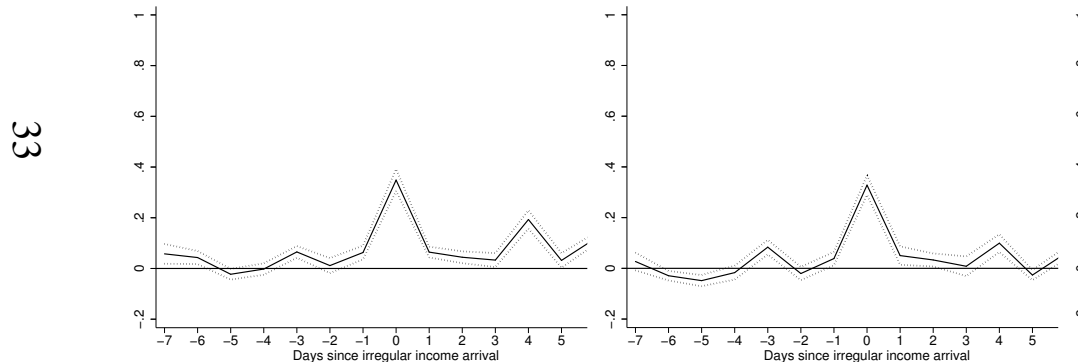

Salary Group 6
Salary Group 7

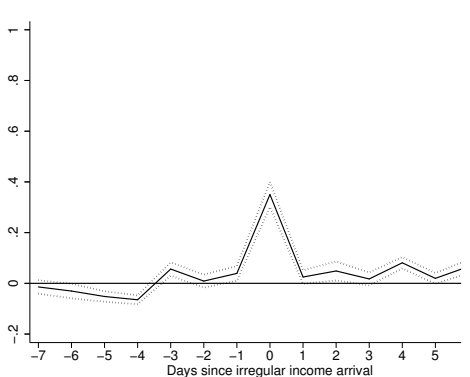

Salary Group 8

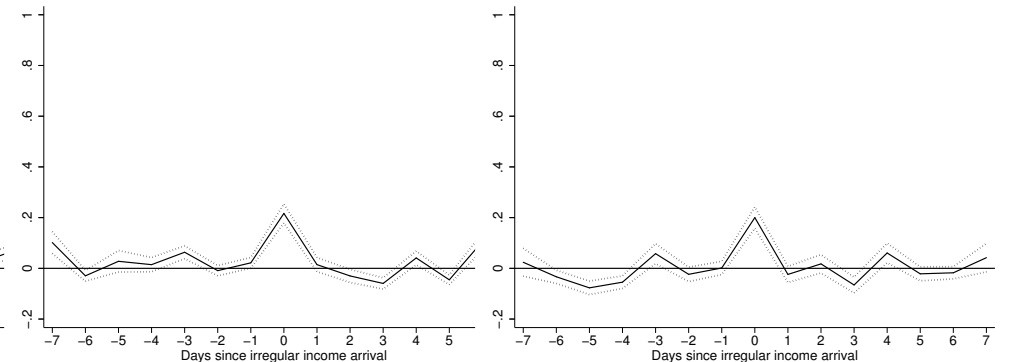

Salary Group 9
Salary Group 10

Figure 4: The Effects of Irregular Income on Spending 
Table 2: The Impact of payments on household spending

\begin{tabular}{|c|c|c|c|c|c|}
\hline & (1) & (2) & (3) & (4) & (5) \\
\hline & Total spending & Grocery spending & Fuel spending & RMF spending & Alcohol spending \\
\hline \multicolumn{6}{|l|}{ Panel A: All individuals } \\
\hline$I\left(\right.$ Payment $\left._{i t}>0\right)$ & $\begin{array}{c}0.448 \\
(0.0084)\end{array}$ & $\begin{array}{c}0.375 \\
(0.0081)\end{array}$ & $\begin{array}{c}0.568 \\
(0.0161)\end{array}$ & $\begin{array}{c}0.235 \\
(0.0077)\end{array}$ & $\begin{array}{c}0.669 \\
(0.0185)\end{array}$ \\
\hline$I\left(\right.$ Regularpayment $\left._{i t}>0\right)$ & $\begin{array}{c}0.464 \\
(0.0090)\end{array}$ & $\begin{array}{c}0.395 \\
(0.0087)\end{array}$ & $\begin{array}{c}0.601 \\
(0.0177)\end{array}$ & $\begin{array}{c}0.241 \\
(0.0083)\end{array}$ & $\begin{array}{c}0.691 \\
(0.0196)\end{array}$ \\
\hline I( Irregularpayment $\left._{i t}>0\right)$ & $\begin{array}{c}0.362 \\
(0.0158)\end{array}$ & $\begin{array}{c}0.237 \\
(0.0142)\end{array}$ & $\begin{array}{c}0.440 \\
(0.0269)\end{array}$ & $\begin{array}{c}0.171 \\
(0.0161)\end{array}$ & $\begin{array}{c}0.618 \\
(0.0430)\end{array}$ \\
\hline$I\left(\right.$ Salary $\left._{i t}>0\right)$ & $\begin{array}{c}0.4523 \\
(0.0099)\end{array}$ & $\begin{array}{c}0.3569 \\
(0.0090)\end{array}$ & $\begin{array}{l}0.6208 \\
(0.0210)\end{array}$ & $\begin{array}{l}0.2200 \\
(0.0088)\end{array}$ & $\begin{array}{l}0.6406 \\
(0.0217)\end{array}$ \\
\hline
\end{tabular}

Standard errors are clustered at the individual level and are within parentheses. Each entry is a separate regression. The salary arrival responses are estimated by salary quartiles while the response to any payments, regular payments, and irregular payments are estimated by total income quartiles. The outcome is the fraction by which individual spending in each category deviates from average daily spending in the day of income arrival. 
Table 3: The Impact of payments on household spending by income quartiles

(1)

(2)

(3)

(4)

(5)

Total spending Grocery spending Fuel spending RMF spending Alcohol spending

Panel A: 1st salary quartile

\begin{tabular}{|c|c|c|c|c|c|}
\hline$I\left(\right.$ Payment $\left._{i t}>0\right)$ & $\begin{array}{c}0.680 \\
(0.0182)\end{array}$ & $\begin{array}{c}0.628 \\
(0.0195)\end{array}$ & $\begin{array}{c}0.702 \\
(0.0274)\end{array}$ & $\begin{array}{c}0.440 \\
(0.0175)\end{array}$ & $\begin{array}{c}1.006 \\
(0.0423)\end{array}$ \\
\hline$I\left(\right.$ Regularpayment $\left._{i t}>0\right)$ & $\begin{array}{c}0.694 \\
(0.0193)\end{array}$ & $\begin{array}{c}0.645 \\
(0.0209)\end{array}$ & $\begin{array}{c}0.719 \\
(0.0291)\end{array}$ & $\begin{array}{c}0.454 \\
(0.0187)\end{array}$ & $\begin{array}{c}1.005 \\
(0.0441)\end{array}$ \\
\hline$I\left(\right.$ Irregularpayment $\left._{i t}>0\right)$ & $\begin{array}{c}0.608 \\
(0.0413)\end{array}$ & $\begin{array}{c}0.504 \\
(0.0348)\end{array}$ & $\begin{array}{c}0.667 \\
(0.0653)\end{array}$ & $\begin{array}{c}0.304 \\
(0.0331)\end{array}$ & $\begin{array}{c}1.207 \\
(0.1179)\end{array}$ \\
\hline$I\left(\right.$ Salary $\left._{i t}>0\right)$ & $\begin{array}{c}0.5890 \\
(0.0235)\end{array}$ & $\begin{array}{c}0.5423 \\
(0.0269)\end{array}$ & $\begin{array}{c}0.6517 \\
(0.0411)\end{array}$ & $\begin{array}{c}0.4463 \\
(0.0269)\end{array}$ & $\begin{array}{r}0.6904 \\
(0.0630) \\
\end{array}$ \\
\hline \multicolumn{6}{|l|}{ Panel B: 2nd salary quartile } \\
\hline$I\left(\right.$ Payment $\left._{i t}>0\right)$ & $\begin{array}{c}0.494 \\
(0.0164)\end{array}$ & $\begin{array}{c}0.418 \\
(0.0156)\end{array}$ & $\begin{array}{c}0.574 \\
(0.0288)\end{array}$ & $\begin{array}{c}0.248 \\
(0.0149)\end{array}$ & $\begin{array}{c}0.693 \\
(0.0358)\end{array}$ \\
\hline$I\left(\right.$ Regularpayment $\left._{i t}>0\right)$ & $\begin{array}{c}0.511 \\
(0.0175)\end{array}$ & $\begin{array}{c}0.437 \\
(0.0166)\end{array}$ & $\begin{array}{c}0.602 \\
(0.0311)\end{array}$ & $\begin{array}{c}0.250 \\
(0.0158)\end{array}$ & $\begin{array}{c}0.728 \\
(0.0378)\end{array}$ \\
\hline$I\left(\right.$ Irregularpayment $\left._{i t}>0\right)$ & $\begin{array}{c}0.373 \\
(0.0304)\end{array}$ & $\begin{array}{c}0.274 \\
(0.0299)\end{array}$ & $\begin{array}{c}0.399 \\
(0.0505)\end{array}$ & $\begin{array}{c}0.205 \\
(0.0359)\end{array}$ & $\begin{array}{c}0.589 \\
(0.0889)\end{array}$ \\
\hline$I\left(\right.$ Salary $\left._{i t}>0\right)$ & $\begin{array}{l}0.5093 \\
.01803 \\
\end{array}$ & $\begin{array}{c}0.3979 \\
(0.0170) \\
\end{array}$ & $\begin{array}{c}0.6255 \\
(0.0352) \\
\end{array}$ & $\begin{array}{c}0.2200 \\
(0.0164)\end{array}$ & $\begin{array}{c}0.6754 \\
(0.0436) \\
\end{array}$ \\
\hline \multicolumn{6}{|l|}{ Panel C: 3rd salary quartile } \\
\hline$I\left(\right.$ Payment $\left._{i t}>0\right)$ & $\begin{array}{c}0.346 \\
(0.0149)\end{array}$ & $\begin{array}{c}0.285 \\
(0.0127)\end{array}$ & $\begin{array}{c}0.502 \\
(0.0327)\end{array}$ & $\begin{array}{c}0.172 \\
(0.0129)\end{array}$ & $\begin{array}{c}0.517 \\
(0.0321)\end{array}$ \\
\hline$I\left(\right.$ Regularpayment $\left._{i t}>0\right)$ & $\begin{array}{c}0.345 \\
(0.0162)\end{array}$ & $\begin{array}{c}0.298 \\
(0.0138)\end{array}$ & $\begin{array}{c}0.535 \\
(0.0368)\end{array}$ & $\begin{array}{c}0.161 \\
(0.0138)\end{array}$ & $\begin{array}{c}0.525 \\
(0.0340)\end{array}$ \\
\hline$I\left(\right.$ Irregularpayment $\left._{i t}>0\right)$ & $\begin{array}{c}0.353 \\
(0.0273)\end{array}$ & $\begin{array}{c}0.191 \\
(0.0229)\end{array}$ & $\begin{array}{c}0.417 \\
(0.0493)\end{array}$ & $\begin{array}{c}0.218 \\
(0.0290)\end{array}$ & $\begin{array}{c}0.481 \\
(0.0666)\end{array}$ \\
\hline$I\left(\right.$ Salary $\left._{i t}>0\right)$ & $\begin{array}{c}0.373 \\
(0.0151) \\
\end{array}$ & $\begin{array}{c}0.303 \\
(0.0139) \\
\end{array}$ & $\begin{array}{c}0.545 \\
(0.0332) \\
\end{array}$ & $\begin{array}{c}0.133 \\
(0.0144) \\
\end{array}$ & $\begin{array}{c}0.485 \\
(0.0378) \\
\end{array}$ \\
\hline \multicolumn{6}{|l|}{ Panel D: 4th salary quartile } \\
\hline$I\left(\right.$ Payment $\left._{i t}>0\right)$ & $\begin{array}{c}0.263 \\
(0.0153)\end{array}$ & $\begin{array}{c}0.161 \\
(0.0118)\end{array}$ & $\begin{array}{c}0.514 \\
(0.0415)\end{array}$ & $\begin{array}{c}0.081 \\
(0.0143)\end{array}$ & $\begin{array}{c}0.406 \\
(0.0345)\end{array}$ \\
\hline$I\left(\right.$ Regularpayment $\left._{i t}>0\right)$ & $\begin{array}{c}0.280 \\
(0.0168)\end{array}$ & $\begin{array}{c}0.172 \\
(0.0125)\end{array}$ & $\begin{array}{c}0.564 \\
(0.0476)\end{array}$ & $\begin{array}{c}0.083 \\
(0.0153)\end{array}$ & $\begin{array}{c}0.437 \\
(0.0373)\end{array}$ \\
\hline$I\left(\right.$ Irregularpayment $\left._{i t}>0\right)$ & $\begin{array}{c}0.228 \\
(0.0267)\end{array}$ & $\begin{array}{c}0.118 \\
(0.0238)\end{array}$ & $\begin{array}{c}0.386 \\
(0.0511)\end{array}$ & $\begin{array}{c}0.035 \\
(0.0284)\end{array}$ & $\begin{array}{c}0.348 \\
(0.0782)\end{array}$ \\
\hline$I\left(\right.$ Salary $\left._{i t}>0\right)$ & $\begin{array}{c}0.315 \\
(0.0134)\end{array}$ & $\begin{array}{c}0.213 \\
(0.0107)\end{array}$ & $\begin{array}{c}0.574 \\
(0.0345)\end{array}$ & $\begin{array}{c}0.082 \\
(0.0123)\end{array}$ & $\begin{array}{c}0.538 \\
(0.0352)\end{array}$ \\
\hline
\end{tabular}

Standard errors are clustered at the individual level and are within parentheses. Each entry is a separate regression. The salary arrival responses are estimated by salary quartiles while the response to any payments, regular payments, and irregular payments are estimated by total income quartiles. variable. The outcome is the fraction by which individual spending in each category deviates from average daily spending in the day of income arrival. 


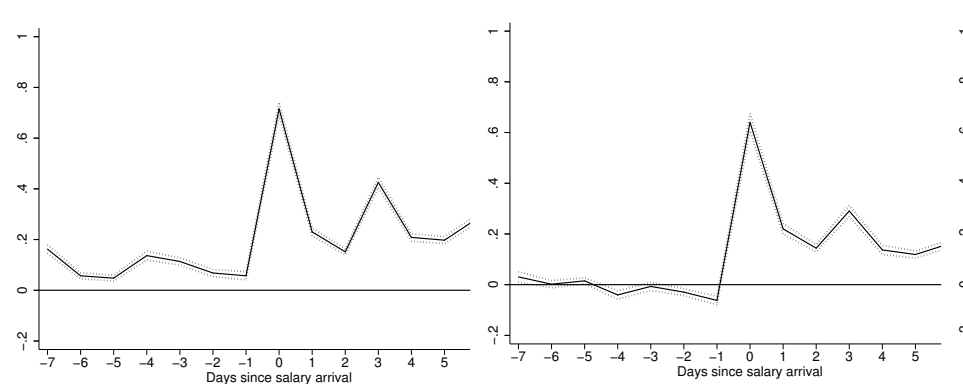

Salary Group 1

Salary Group 2

Salary Group 3

Salary Group 4

Salary Group 5

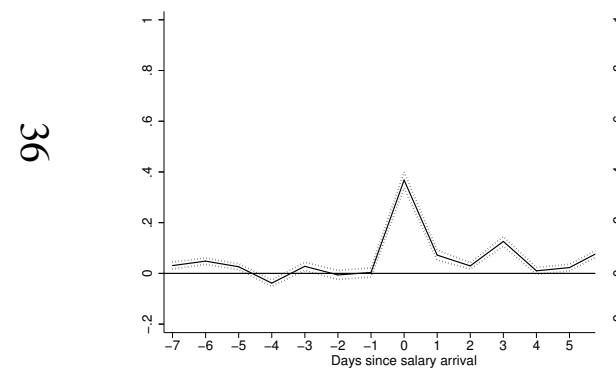

Salary Group 6

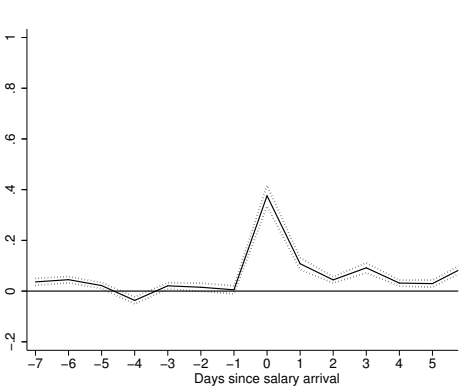

Salary Group 7

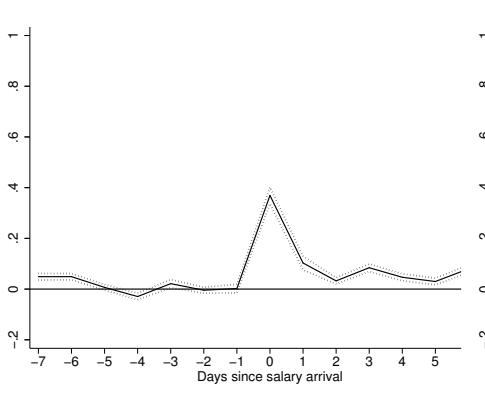

Salary Group 8

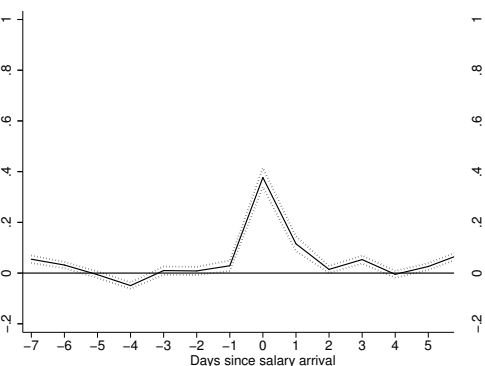

Salary Group 9

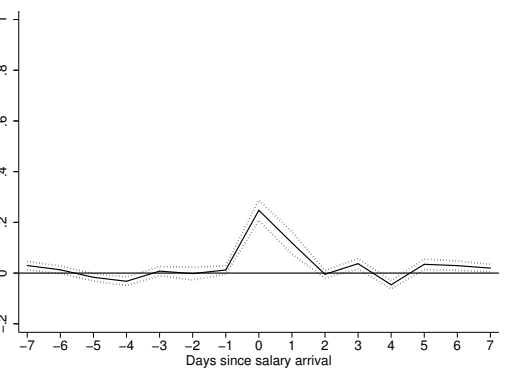

Salary Group 10

Figure 5: The Effects of Paycheck Arrival on Necessary Spending 


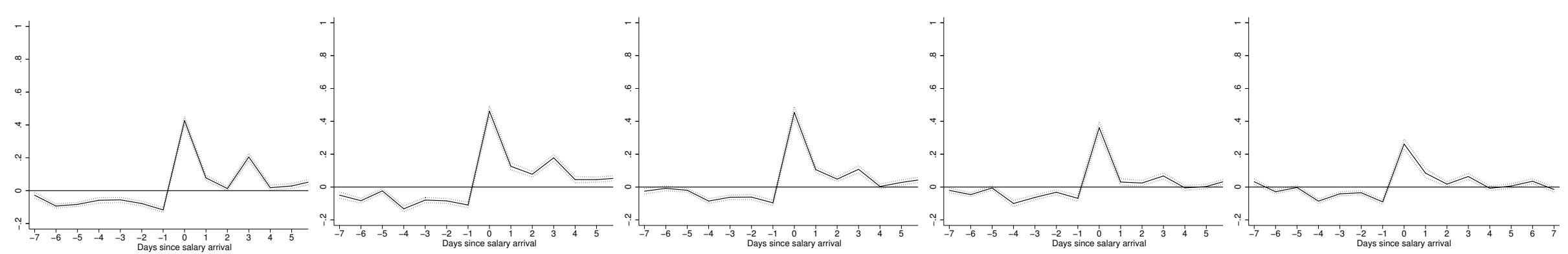

Salary Group 1

Salary Group 2

Salary Group 3

Salary Group 4

Salary Group 5

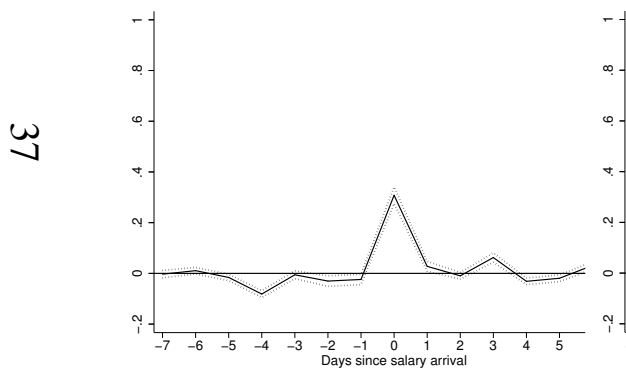

Salary Group 6

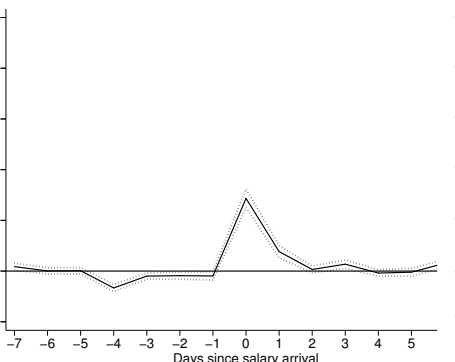

Salary Group 7

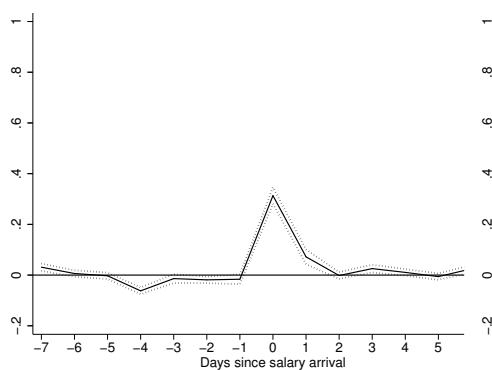

Salary Group 8

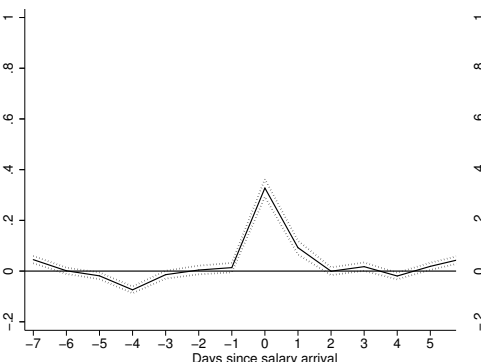

Salary Group 9

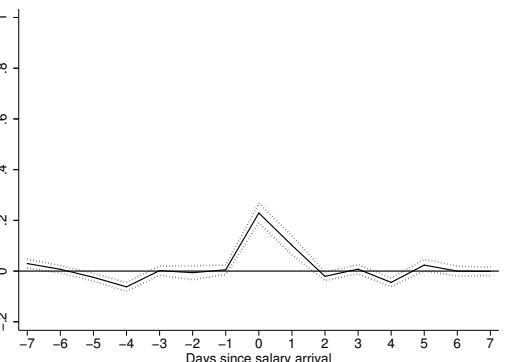

Salary Group 10

Figure 6: The Effects of Paycheck Arrival on discretionary Spending 


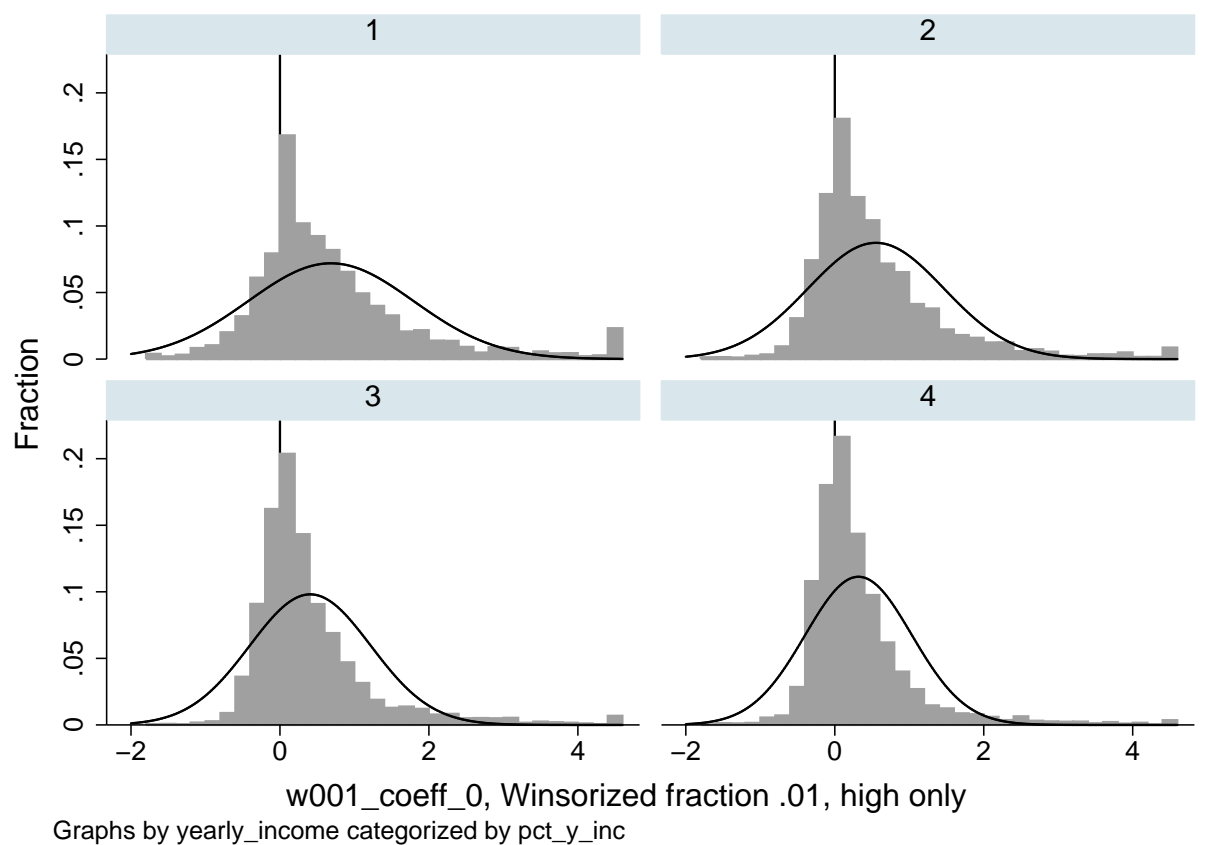

Graphs by yearly_income categorized by pct_y_inc

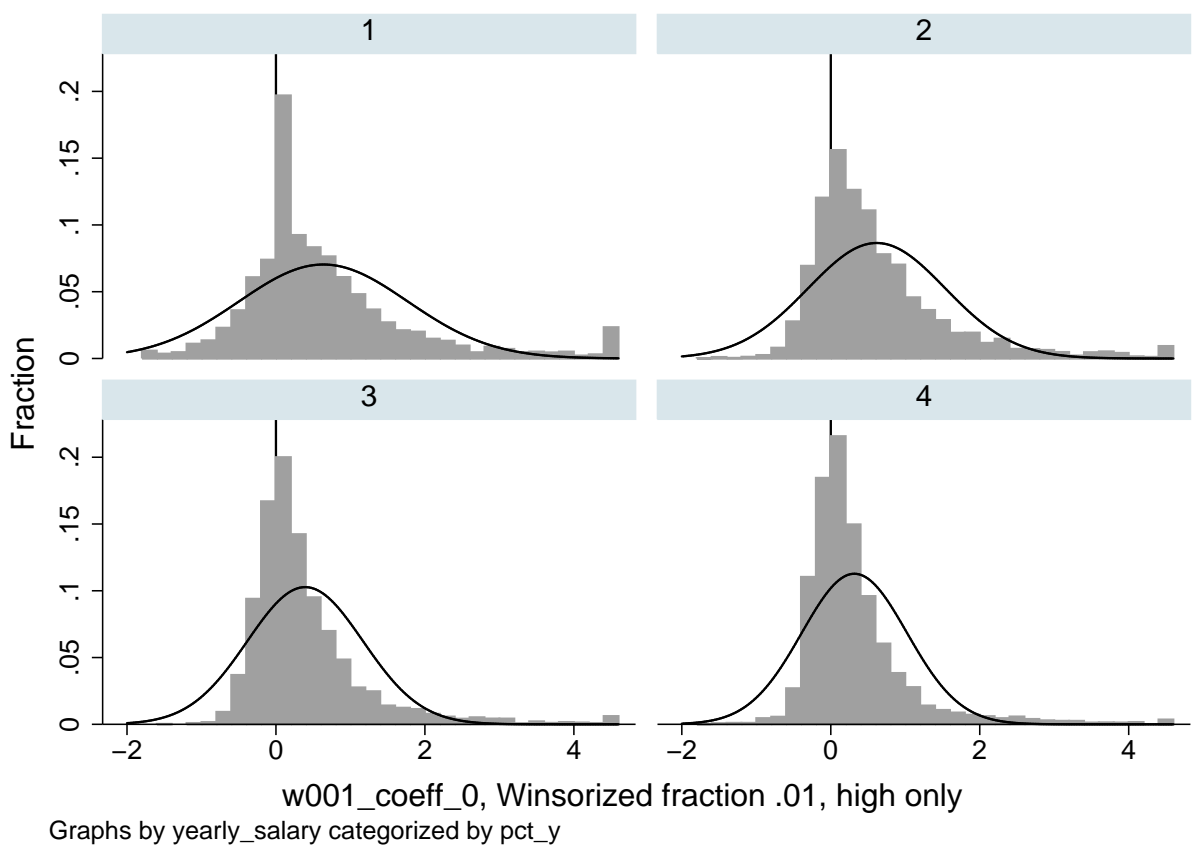

Figure 7: The Distribution of Payday Coefficients for Individuals by Income and Salary Quartiles 
Table 4: Internal and External Margins of Spending Reaction

\begin{tabular}{|c|c|c|c|c|c|c|c|c|c|c|c|}
\hline & (1) & (2) & (3) & (4) & (5) & (6) & (7) & (8) & (9) & (10) & (11) \\
\hline Spending: & Any & Groceries & Fuel & Alcohol & $\begin{array}{l}\text { Ready Made } \\
\text { Food }\end{array}$ & $\begin{array}{c}\text { Home } \\
\text { Improvements }\end{array}$ & $\begin{array}{l}\text { Home } \\
\text { Security }\end{array}$ & Vehicles & $\begin{array}{c}\text { Clothing and } \\
\text { Accessories }\end{array}$ & $\begin{array}{c}\text { Sports and } \\
\text { Activities }\end{array}$ & Pharmacies \\
\hline \multicolumn{12}{|c|}{ Panel A: External margin } \\
\hline Payment & $\begin{array}{c}0.113 * * * \\
(0.0009)\end{array}$ & $\begin{array}{c}0.077 * * * \\
(0.0007)\end{array}$ & $\begin{array}{c}0.052 * * * \\
(0.0006)\end{array}$ & $\begin{array}{c}0.021 * * * \\
(0.0003)\end{array}$ & $\begin{array}{c}0.054 * * * \\
(0.0006)\end{array}$ & $\begin{array}{c}0.018 * * * \\
(0.0003)\end{array}$ & $\begin{array}{c}0.001 * * * \\
(0.0001)\end{array}$ & $\begin{array}{c}0.014 * * * \\
(0.0002)\end{array}$ & $\begin{array}{l}0.010 * * * \\
(0.0002)\end{array}$ & $\begin{array}{c}0.008 * * * \\
(0.0002)\end{array}$ & $\begin{array}{c}0.015 * * * \\
(0.0003)\end{array}$ \\
\hline Regular & $0.096 * * *$ & $0.068 * * *$ & $0.048 * * *$ & $0.023 * * *$ & $0.045 * * *$ & $0.015 * * *$ & $0.001 * * *$ & $0.014 * * *$ & $0.010 * * *$ & $0.008 * * *$ & $0.015 * * *$ \\
\hline payment & $(0.0009)$ & $(0.0008)$ & $(0.0007)$ & $(0.0004)$ & $(0.0007)$ & $(0.0003)$ & $(0.0002)$ & $(0.0003)$ & $(0.0002)$ & $(0.0003)$ & $(0.0003)$ \\
\hline Irregular & $0.120 * * *$ & $0.080 * * *$ & $0.054 * * *$ & $0.019 * * *$ & $0.058 * * *$ & $0.021 * * *$ & $0.001 * * *$ & $0.014 * * *$ & $0.010 * * *$ & $0.008 * * *$ & $0.015 * * *$ \\
\hline payment & $(0.0012)$ & $(0.0009)$ & $(0.0008)$ & $(0.0004)$ & $(0.0009)$ & $(0.0003)$ & $(0.0001)$ & $(0.0003)$ & $(0.0002)$ & $(0.0002)$ & $(0.0003)$ \\
\hline $\begin{array}{l}\text { Salary } \\
\text { check }\end{array}$ & $\begin{array}{c}0.093 * * * \\
(0.0010)\end{array}$ & $\begin{array}{c}0.064 * * * \\
(0.0008)\end{array}$ & $\begin{array}{c}0.047 * * * \\
(0.0008)\end{array}$ & $\begin{array}{c}0.024 * * * \\
(0.0004)\end{array}$ & $\begin{array}{c}0.045 * * * \\
(0.0007)\end{array}$ & $\begin{array}{c}0.014 * * * \\
(0.0004)\end{array}$ & $\begin{array}{c}0.001 * * * \\
(0.0002)\end{array}$ & $\begin{array}{c}0.015 * * * \\
(0.0003)\end{array}$ & $\begin{array}{c}0.009 * * * \\
(0.0002)\end{array}$ & $\begin{array}{c}0.008 * * * \\
(0.0003)\end{array}$ & $\begin{array}{l}0.013 * * * \\
(0.0003)\end{array}$ \\
\hline \multicolumn{12}{|c|}{ Panel B: Internal margin } \\
\hline Payment & $\begin{array}{c}21.5 * * * \\
(0.4)\end{array}$ & $\begin{array}{c}6.6 * * * \\
(0.1)\end{array}$ & $\begin{array}{c}11.4 * * * \\
(0.4)\end{array}$ & $\begin{array}{c}5.3 * * * \\
(0.2)\end{array}$ & $\begin{array}{c}1.9 * * * \\
(0.1)\end{array}$ & $\begin{array}{c}15.5 * * * \\
(0.9)\end{array}$ & $\begin{array}{c}3.0 \\
(2.3)\end{array}$ & $\begin{array}{c}46.5 * * * \\
(4.6)\end{array}$ & $\begin{array}{c}5.3 * * * \\
(0.5)\end{array}$ & $\begin{array}{c}8.9 * * * \\
(0.7)\end{array}$ & $\begin{array}{c}2.0 * * * \\
(0.1)\end{array}$ \\
\hline Regular & $21.4 * * *$ & $8.4 * * *$ & $15.4 * * *$ & $5.1 * * *$ & $2.0^{* * *}$ & $8.1 * * *$ & 4.8 & $17.4 * * *$ & $5.5^{* * *}$ & $5.6 * * *$ & $2.3 * * *$ \\
\hline Payment & $(0.5)$ & $(0.2)$ & $(0.5)$ & $(0.2)$ & $(0.1)$ & $(1.0)$ & (4.1) & (4.9) & $(0.6)$ & $(0.8)$ & $(0.1)$ \\
\hline Irregular & $21.4 * * *$ & $4.8 * * *$ & $7.8 * * *$ & $5.5 * * *$ & $1.8^{* * *}$ & $20.1 * * *$ & 0.4 & $69.7 * * *$ & $4.4 * * *$ & $11.4 * * *$ & $1.6 * * *$ \\
\hline Payment & $(0.6)$ & $(0.1)$ & $(0.4)$ & $(0.2)$ & $(0.1)$ & $(1.2)$ & $(0.5)$ & (6.9) & $(0.6)$ & $(0.9)$ & $(0.1)$ \\
\hline Salary & $20.4 * * *$ & $7.8 * * *$ & $15.6 * * *$ & $5.2 * * *$ & $1.8^{* * *}$ & $8.5^{* * *}$ & 5.5 & $11.9^{* *}$ & $5.3 * * *$ & $5.8 * * *$ & $1.9^{* * *}$ \\
\hline check & $(0.5)$ & $(0.2)$ & $(0.6)$ & $(0.2)$ & $(0.1)$ & (1.1) & (4.6) & (4.9) & $(0.6)$ & $(0.9)$ & $(0.1)$ \\
\hline
\end{tabular}

Standard errors are clustered at the individual level and are within parentheses. Each entry is a separate regression. Panel A shows the effect on the probability of buying the goods under consideration on payday. Panel B compares the expenditure on shopping days when consumers do and do not get paid. 


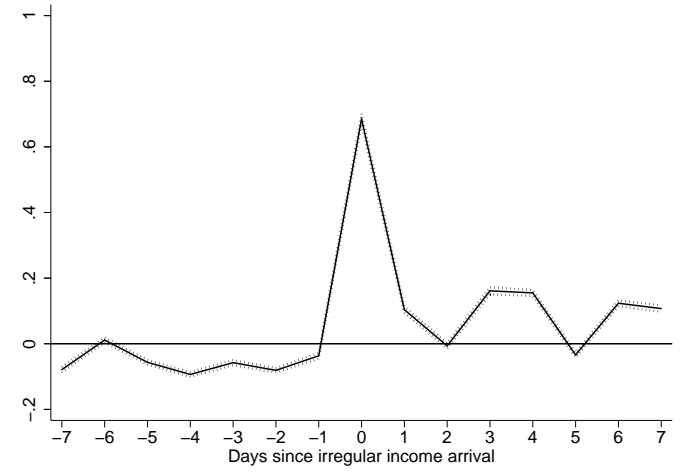

Regular Income Liquidity Group 1

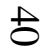

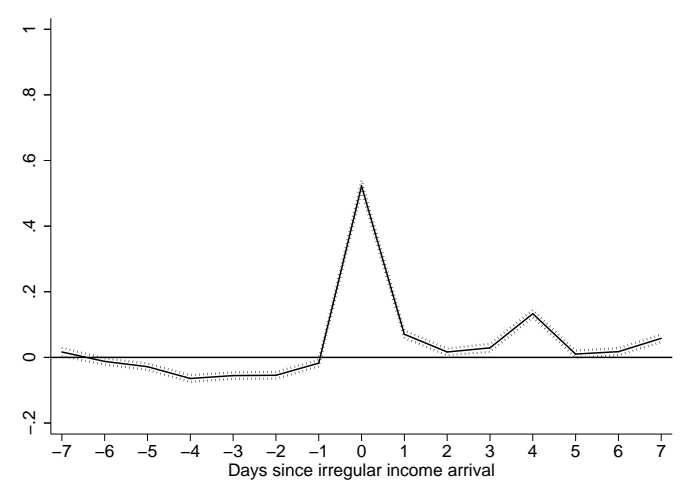

Irregular Income Liquidity Group 1

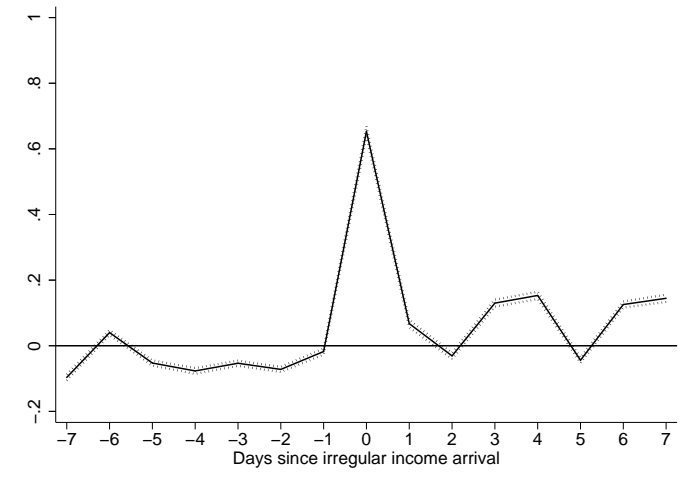

Regular Income Liquidicity Group 2

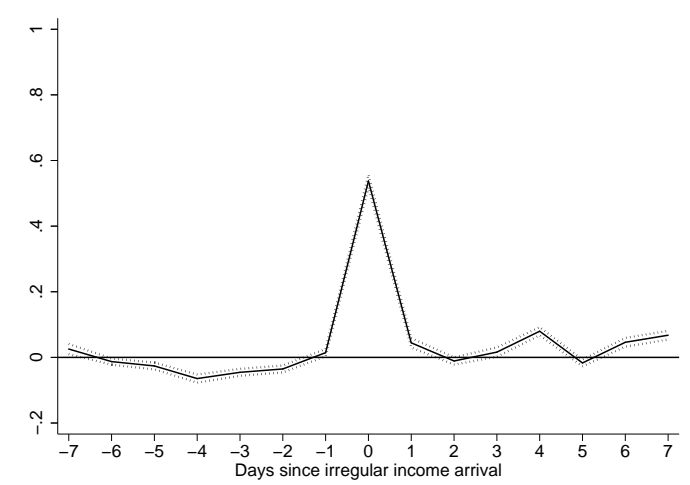

Irregular Income Liquidity Group 2

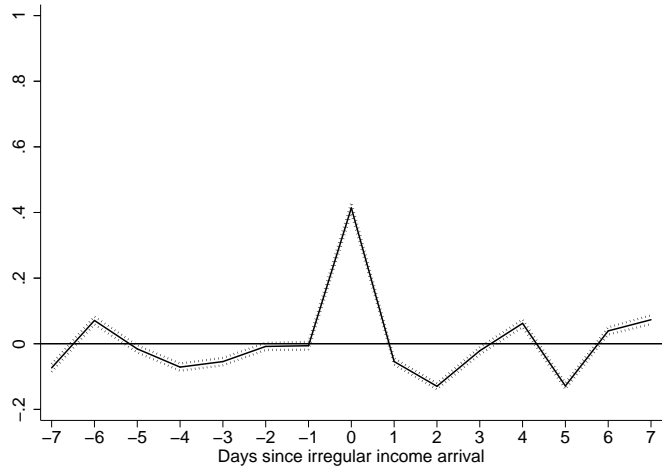

Regular Income Liquidity Group 3

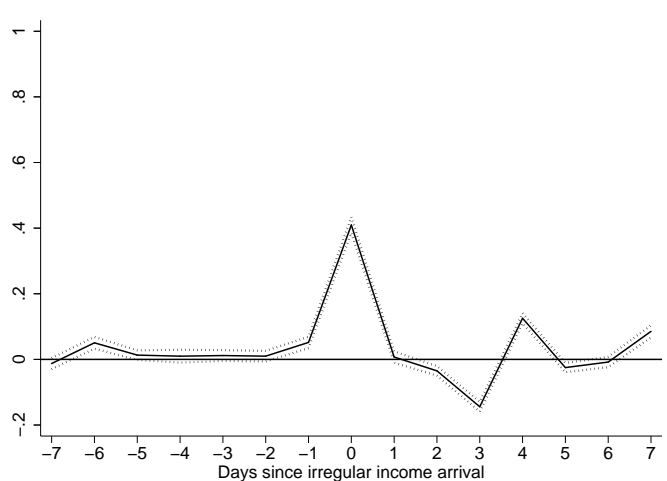

Irregular Income Liquidity Group 3

Figure 8: The Effects of Irregular and Regular Income on Spending by Liquidity (measured by the median number of consumption days held in cash) 


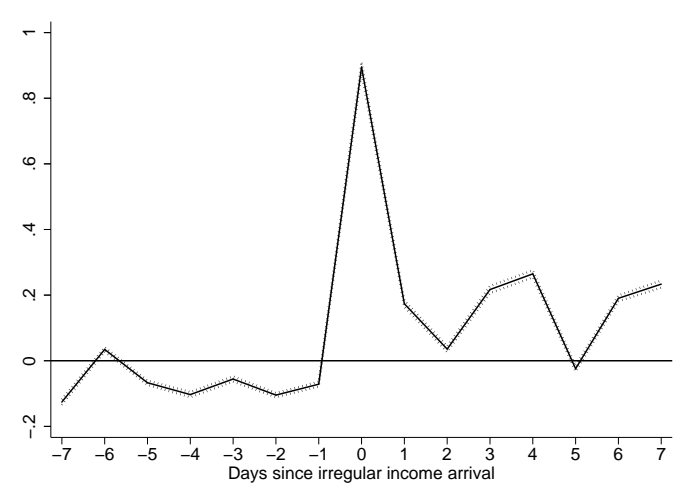

Regular Income Liquidity Group 1

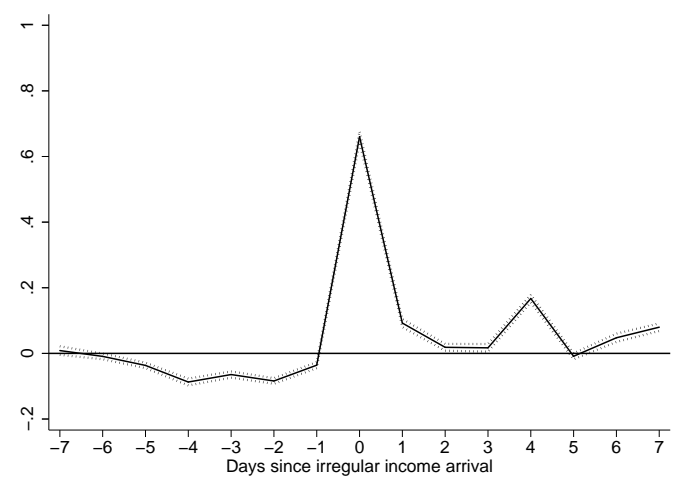

Irregular Income Liquidity Group 1

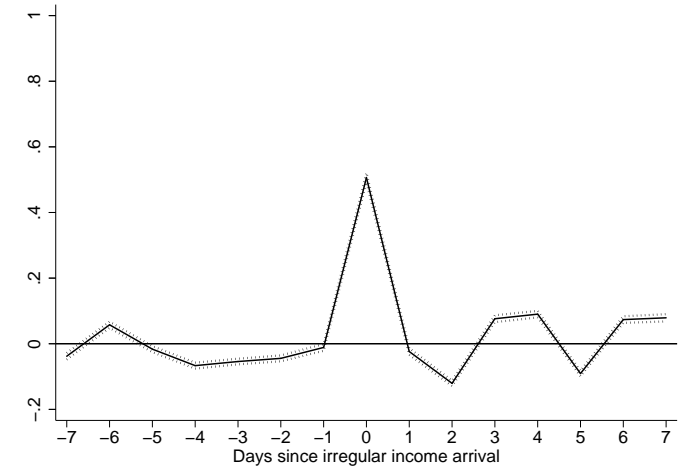

Regular Income Liquidicity Group 2

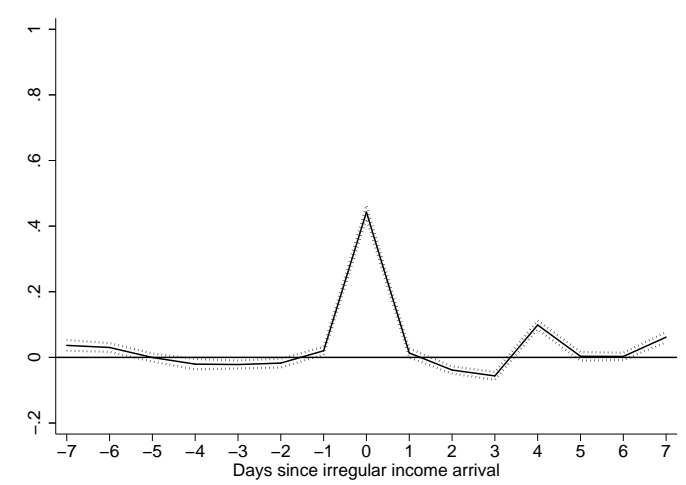

Irregular Income Liquidity Group 2

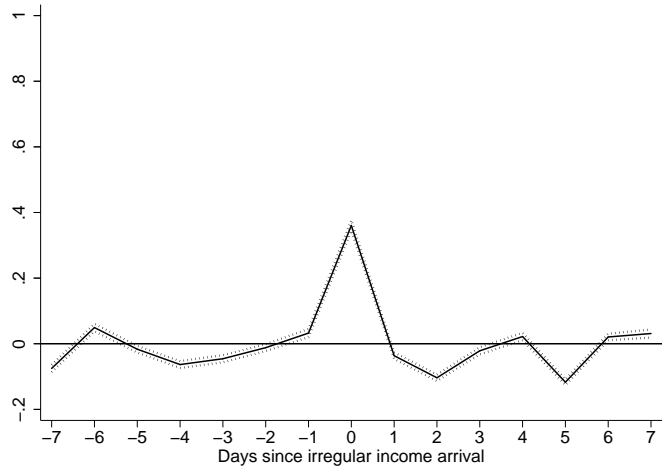

Regular Income Liquidity Group 3

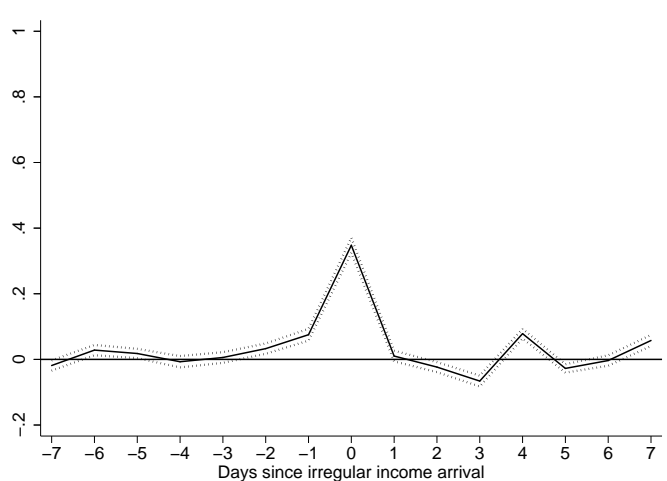

Irregular Income Liquidity Group 3

Figure 9: The Effects of Irregular and Regular Income on Spending by Liquidity (measured by the median number of consumption days held in cash or lines of credit) 


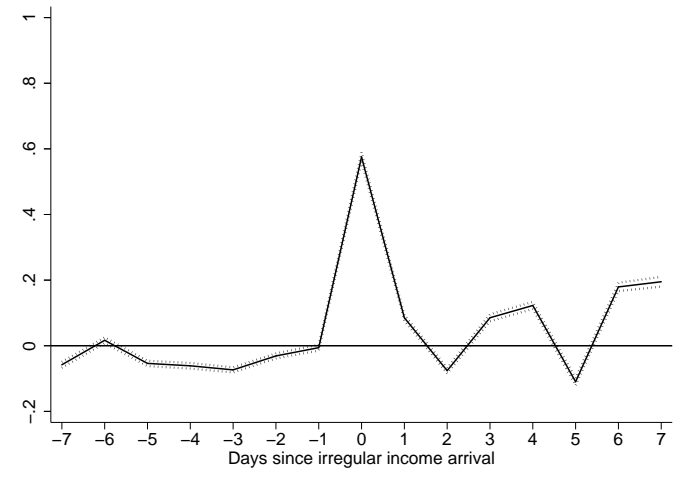

Regular Income Credit Utilization 1

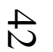

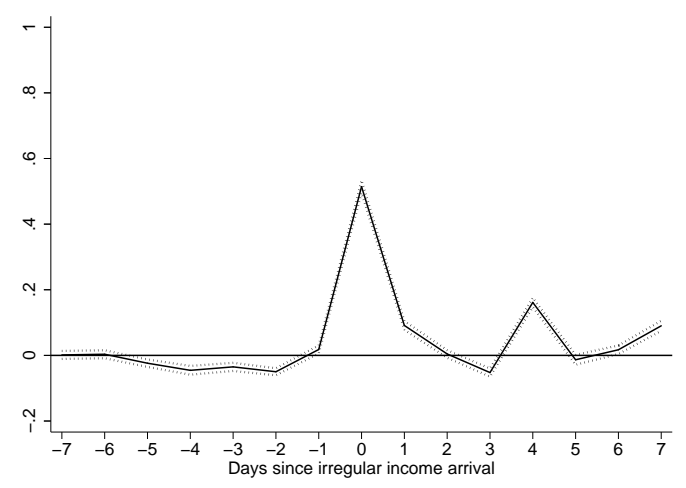

Irregular Income Credit Utilization 1

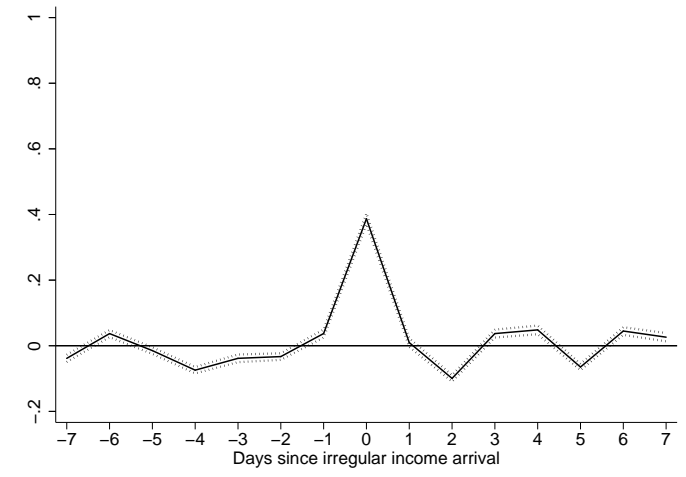

Regular Income Credit Utilization 2

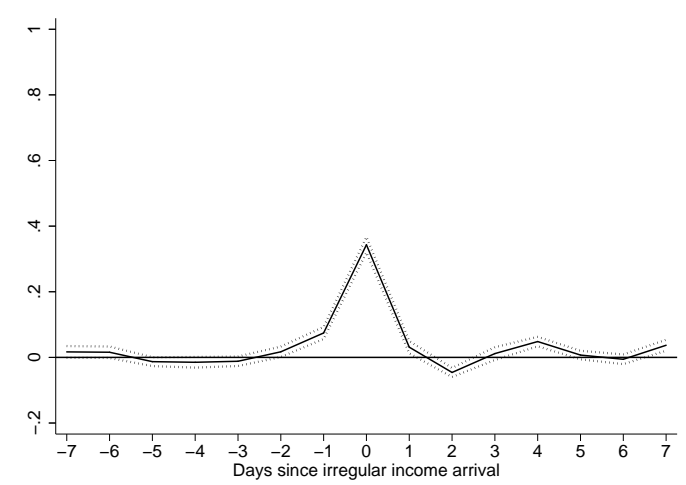

Irregular Income Credit Utilization 2

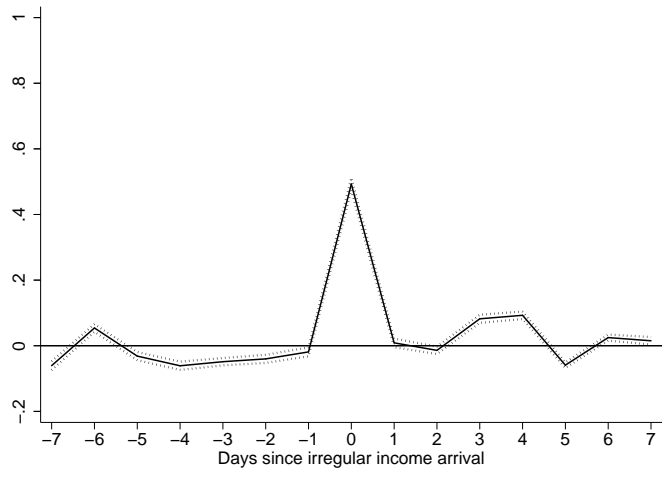

Regular Income Credit Utilization 3

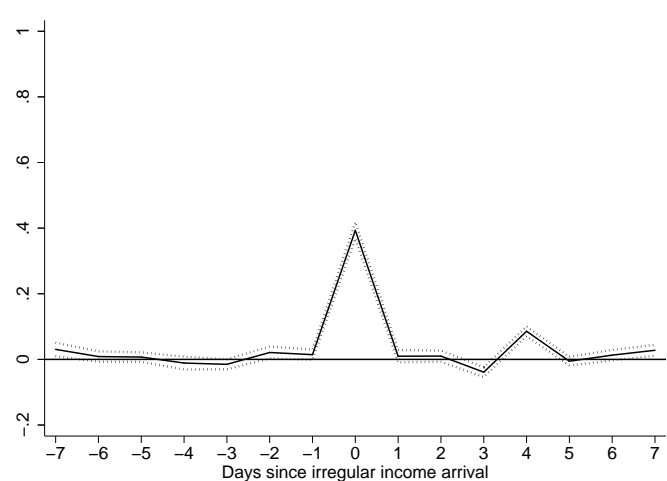

Irregular Income Credit Utilization 3

Figure 10: The Effects of Irregular and Regular Income on Spending by Terciles of Credit Utilization 


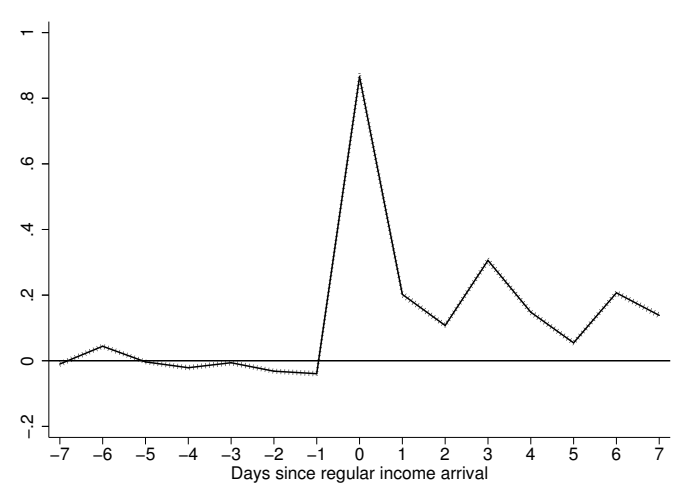

Regular Income Liquidity Group 1

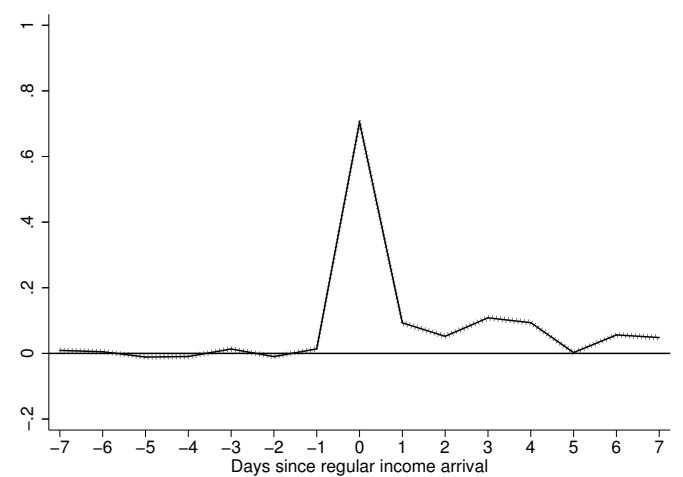

Irregular Income Liquidity Group 1

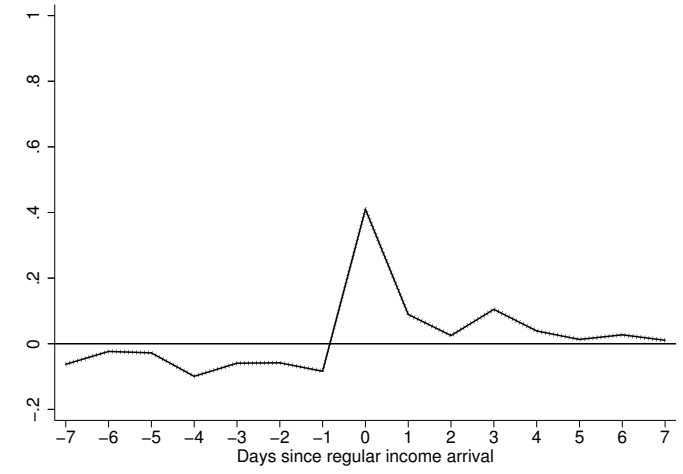

Regular Income Liquidicity Group 2

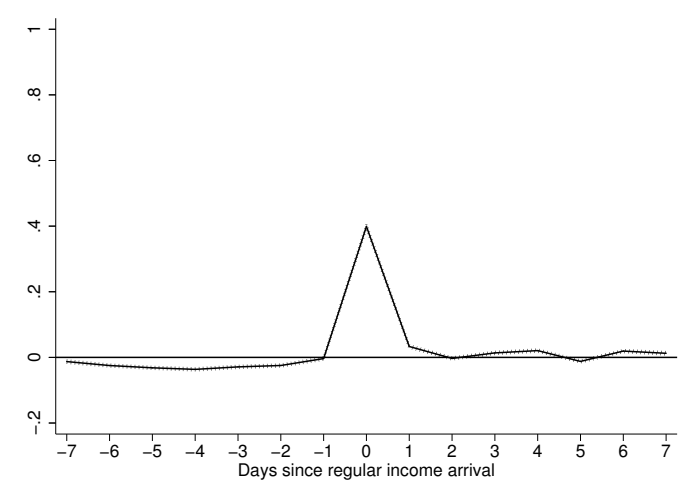

Irregular Income Liquidity Group 2

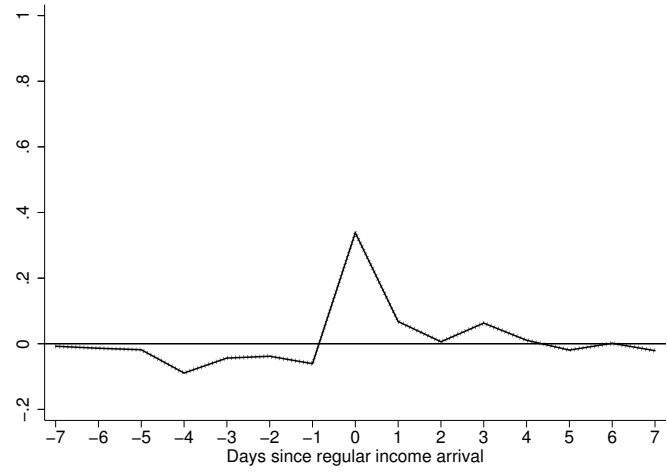

Regular Income Liquidity Group 3

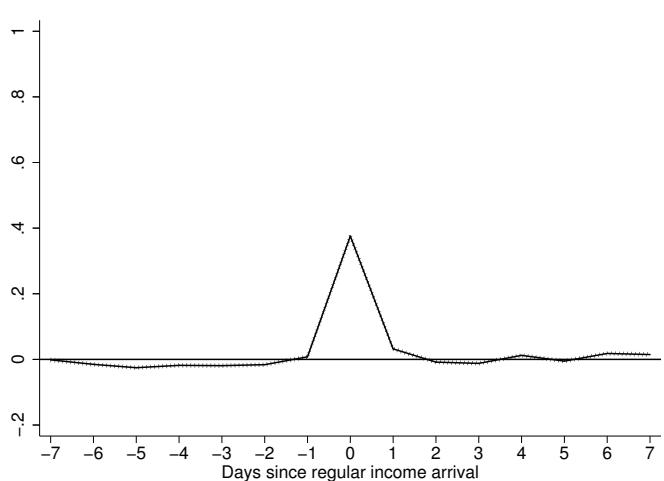

Irregular Income Liquidity Group 3

Figure 11: The Effects of Irregular and Regular Income on Spending by Liquidity (measured by how much people spend as compared to to average day in the last 4 days prior to income arrival) 


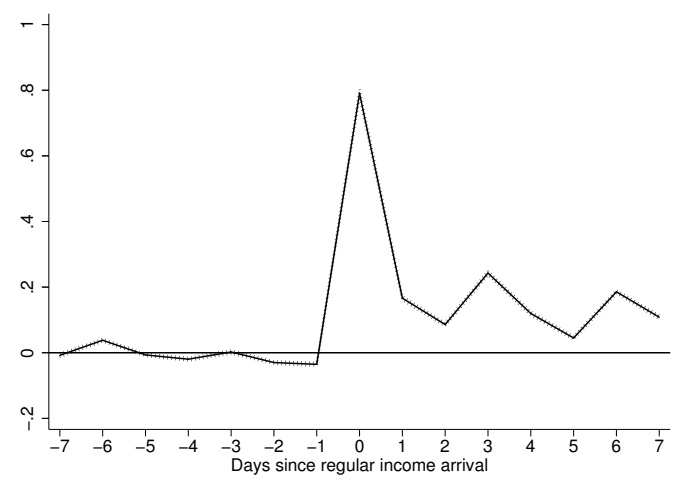

Regular Income Liquidity Group 1

$\stackrel{A}{A}$

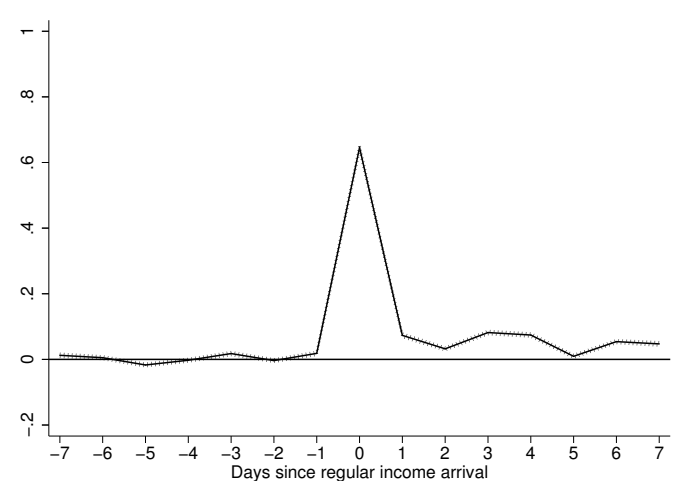

Irregular Income Liquidity Group 1

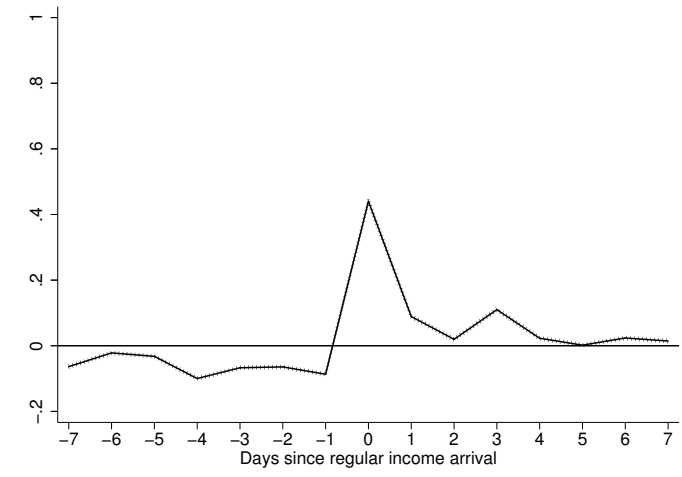

Regular Income Liquidicity Group 2

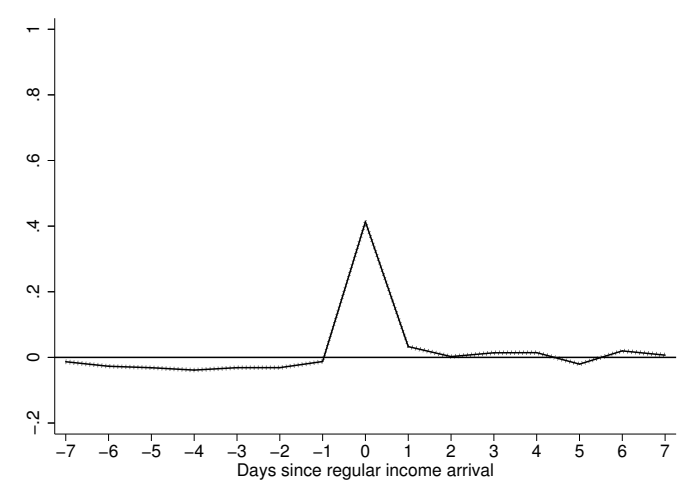

Irregular Income Liquidity Group 2

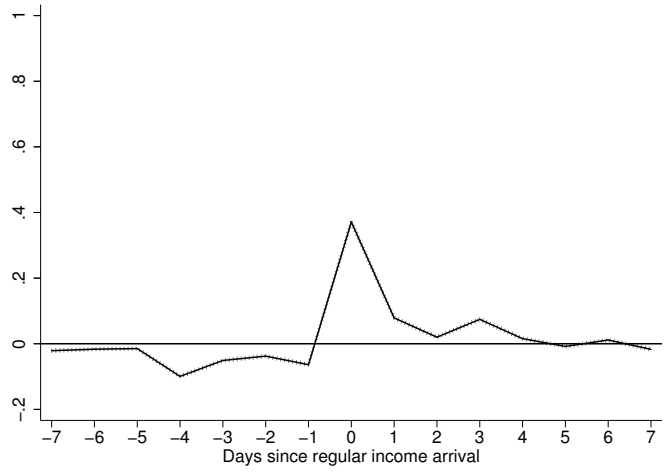

Regular Income Liquidity Group 3

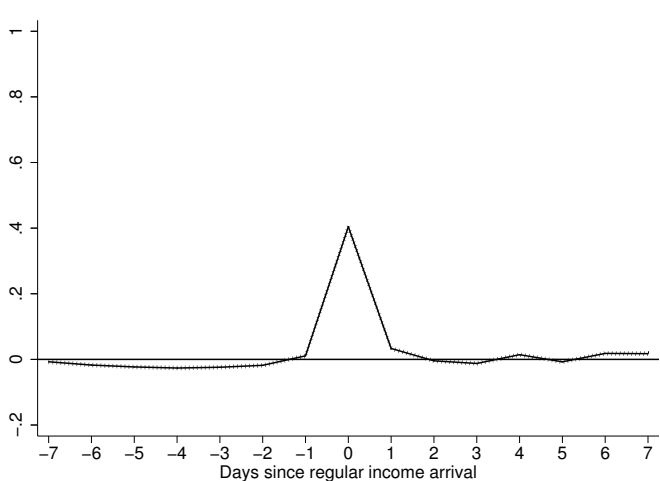

Irregular Income Liquidity Group 3

Figure 12: The Effects of Irregular and Regular Income on Spending by Liquidity (measured by how much people spend on discretionary goods and services as compared to to average day in the last 4 days prior to income arrival) 

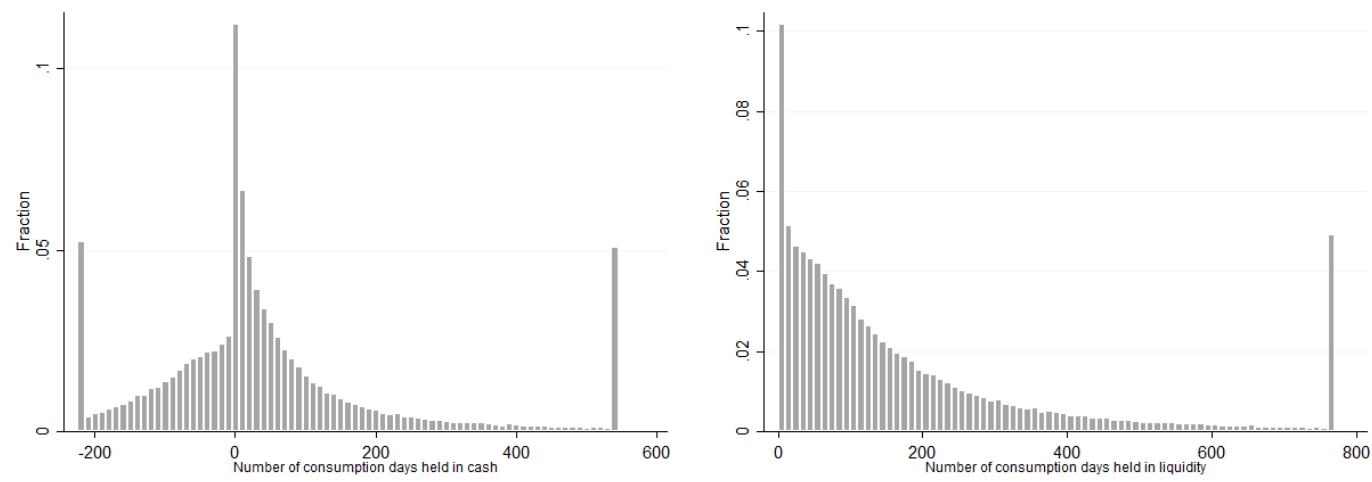

Cash holdings in 10 consumption days Liquidity in 10 consumption days

Figure 13: The Distribution of Cash Holdings and Liquidity before Paydays
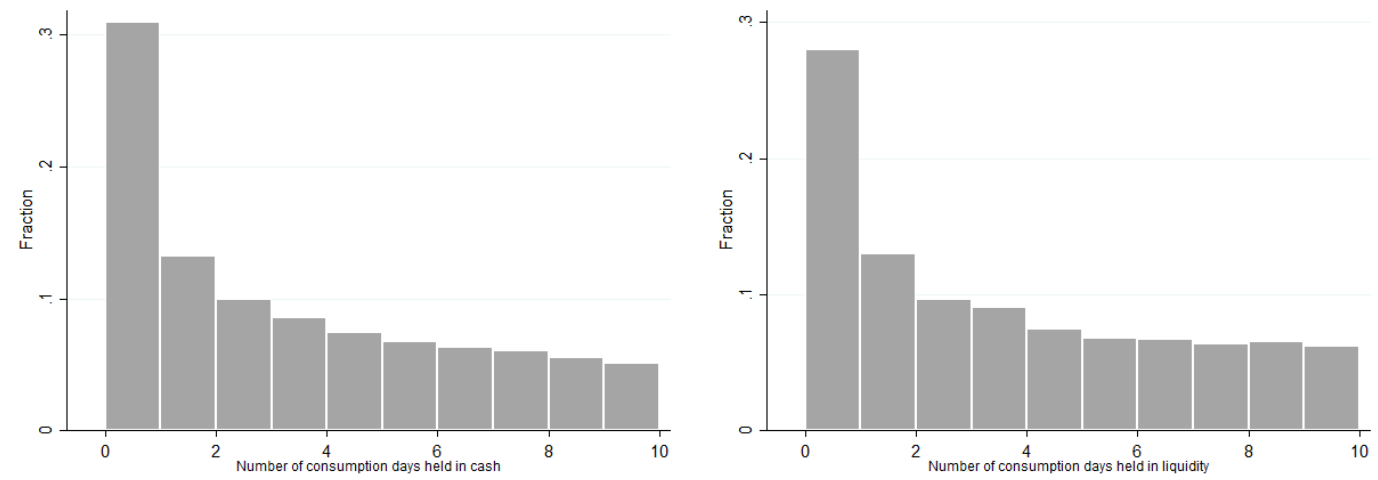

Cash holdings in 10 consumption days Liquidity in 10 consumption days

Figure 14: The Distribution of Cash Holdings and Liquidity before Paydays for Individuals Holding less than ten Days of Spending 
Table 5: Summary Statistics by Terciles of Liquidity in Consumption Days

\begin{tabular}{lccc}
\hline \hline & $(1)$ & $(2)$ & $(3)$ \\
monthly income & 362,714 & 496,280 & 599,862 \\
age & 36 & 41 & 45 \\
spouse & 0.16 & 0.21 & 0.20 \\
savings account balance & 20,463 & 77,424 & $1,122,701$ \\
checking account balance & $-220,787$ & $-149,808$ & 331,403 \\
credit-card balance & $-132,311$ & $-216,989$ & $-222,292$ \\
checking account limit & 311,311 & 433,727 & 440,056 \\
credit-card limit & 241,061 & 626,274 & $1,027,097$ \\
cash & $-200,323$ & $-72,385$ & $1,454,103$ \\
liquidity & 219,738 & 770,627 & $2,698,963$ \\
credit utilization & 0.52 & 0.35 & 0.26 \\
checking account utilization & 0.37 & 0.30 & 0.14 \\
payday loan & 41 & 4 & 0 \\
gender & 0.53 & 0.46 & 0.39 \\
average daily spending & 5,558 & 6,291 & 5,731 \\
number of days held in cash & -38 & -14 & 214 \\
number of days held in liquidity & 38 & 123 & 546
\end{tabular}

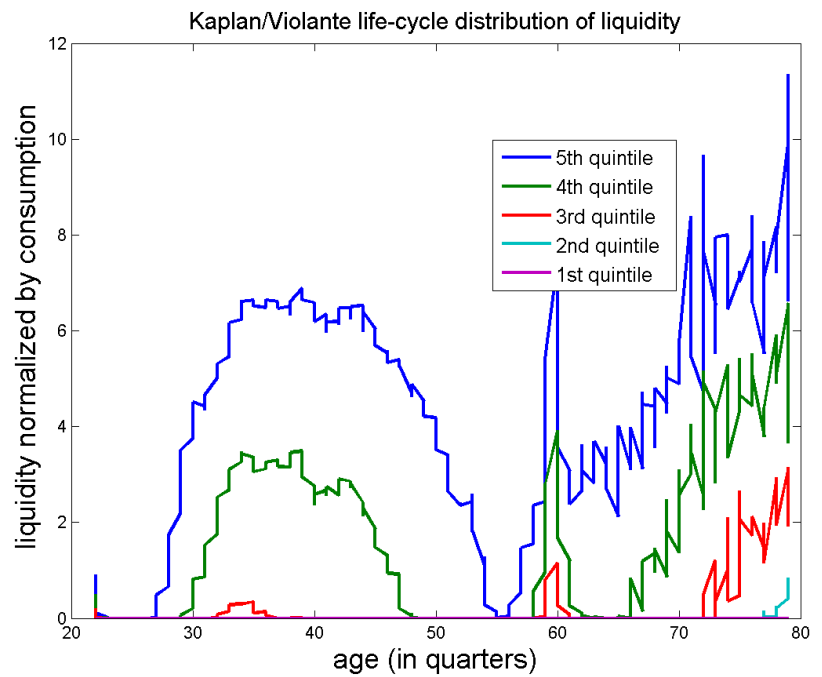

Figure 15: Life-Cycle Profiles of Liquid Asset in Consumption (quarterly) as predicted by the model in Kaplan and Violante (2014b) 

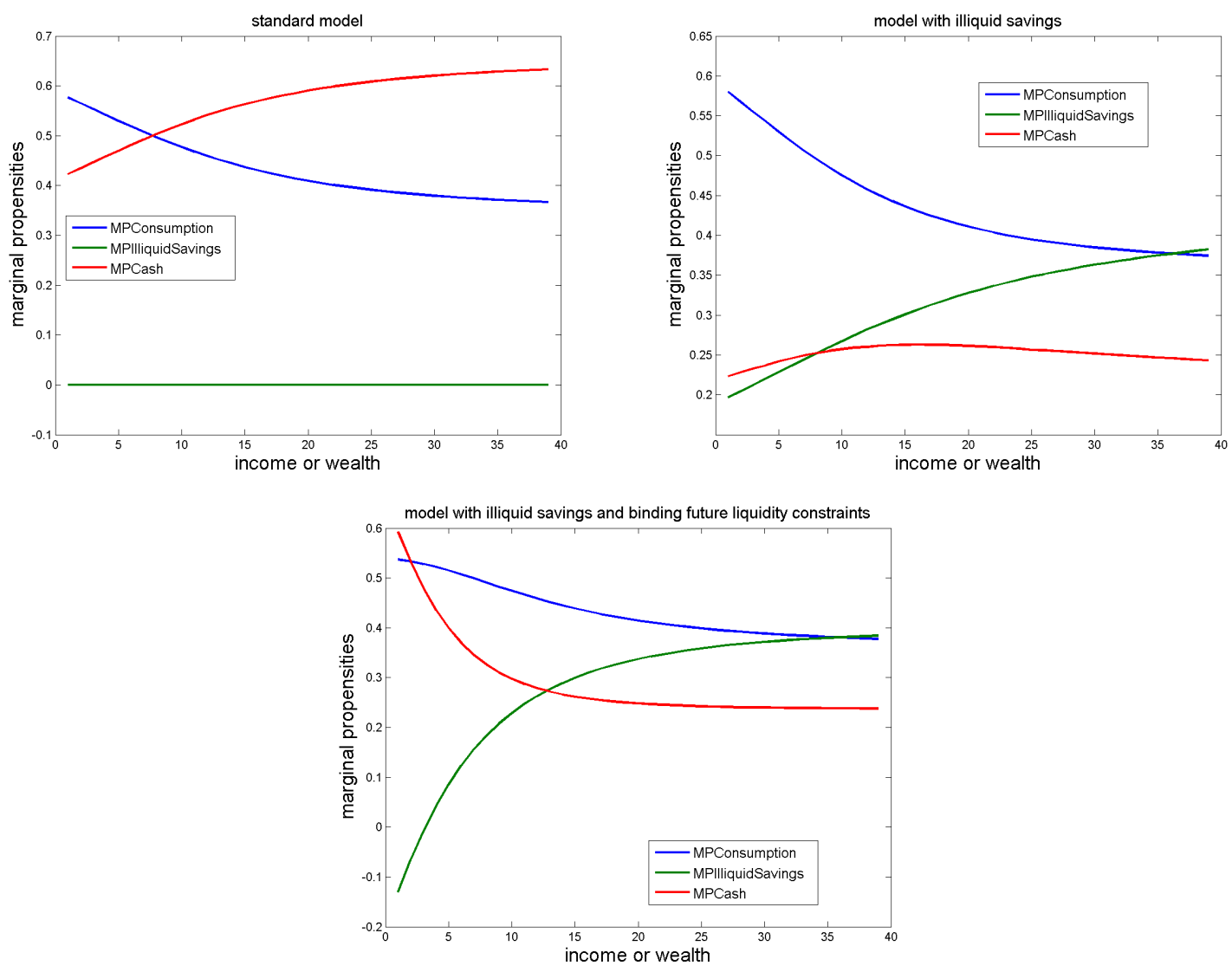

Figure 16: Marginal Propensities to Consume, Save Illiquidly, and Hold on to Cash as implied by Models with and without Illiquid Savings and Future Binding Liquidity Constraints 


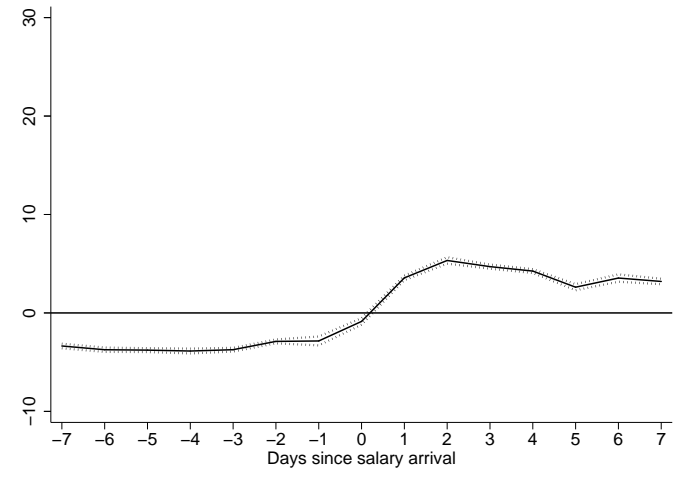

Regular Income Low Liquidity

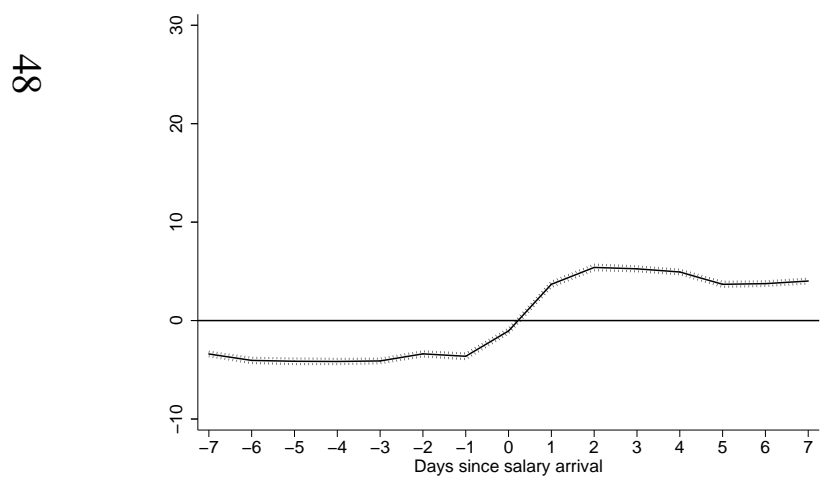

Salary Low Liquidity

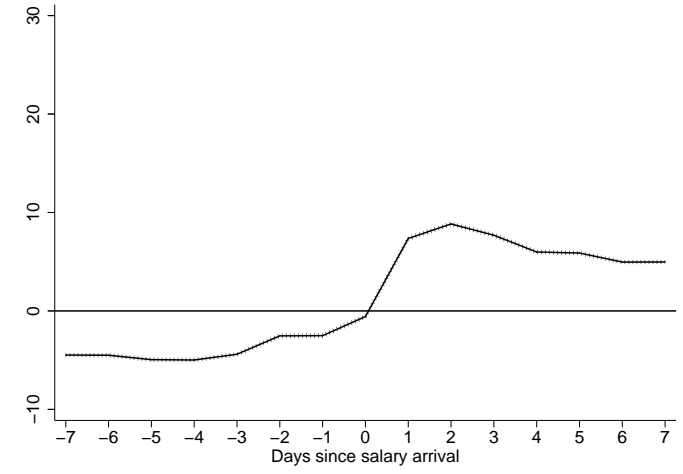

Regular Income Medium Liquidity

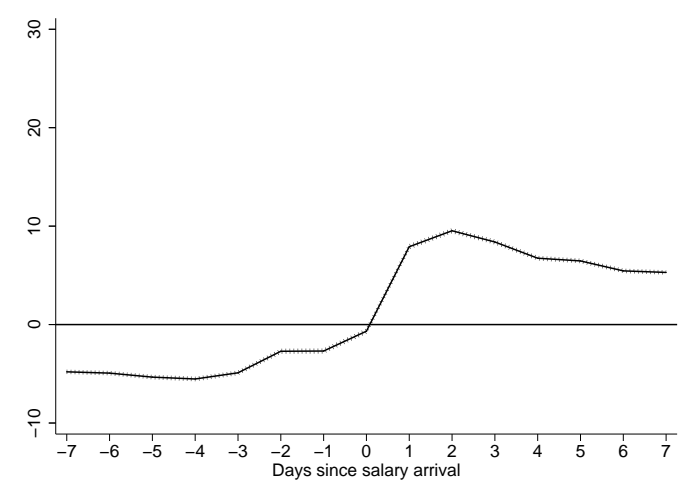

Salary Medium Liquidity

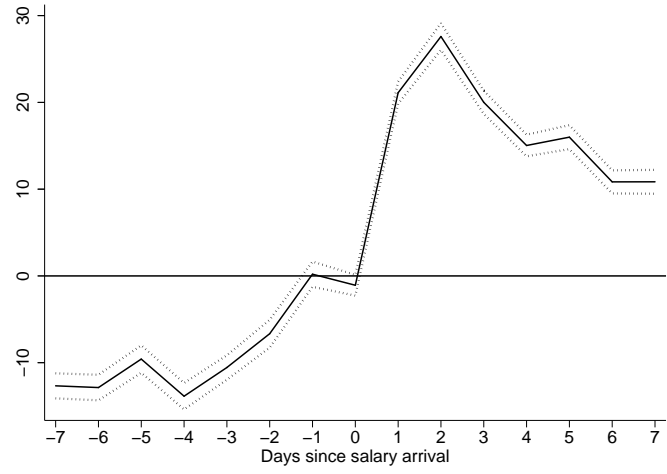

Regular Income High Liquidity

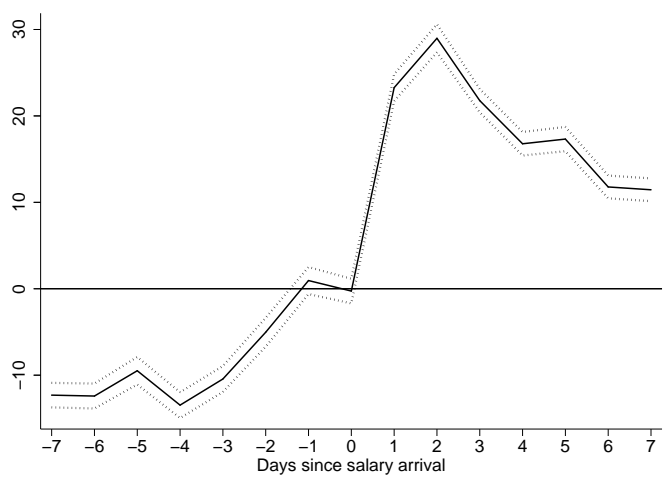

Salary High Liquidity

Figure 17: The Effects of Regular Income and Salary Arrival on Liquidity by Terciles of Consumption Days From Current Liquidity 


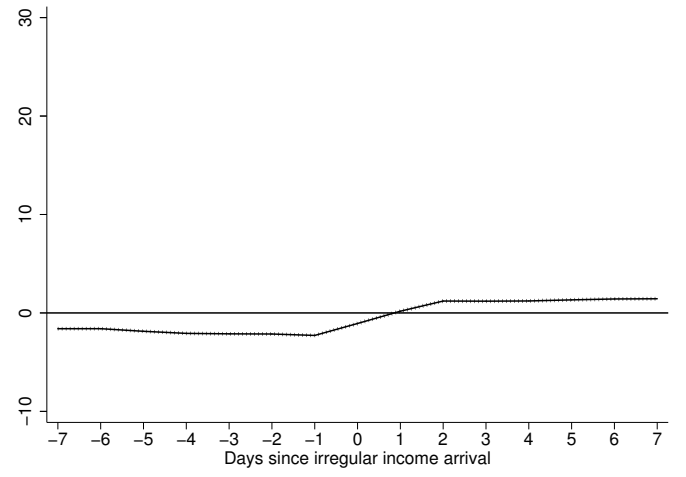

Irregular Income Low Liquidity

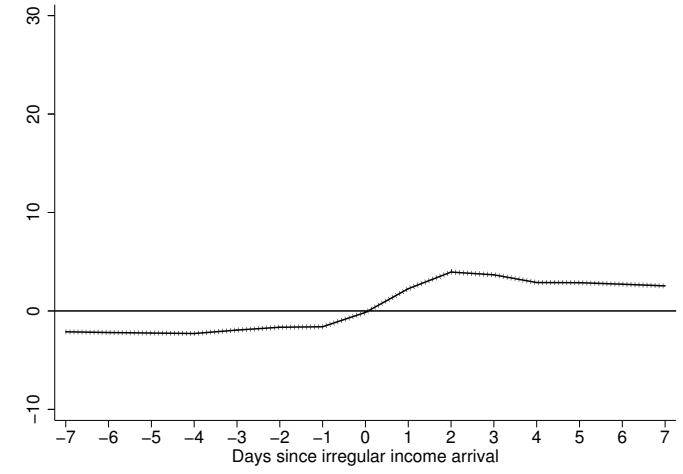

Irregular Income Medium Liquidity

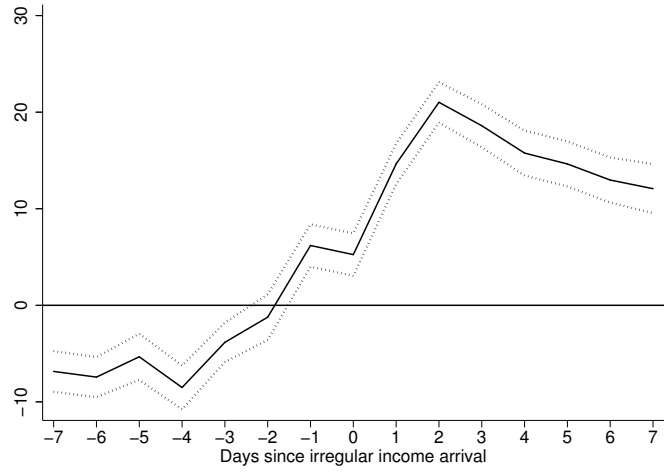

Irregular Income High Liquidity

Figure 18: The Effects of Irregular Income on Liquidity by Terciles of Consumption Days From Current Liquidity 


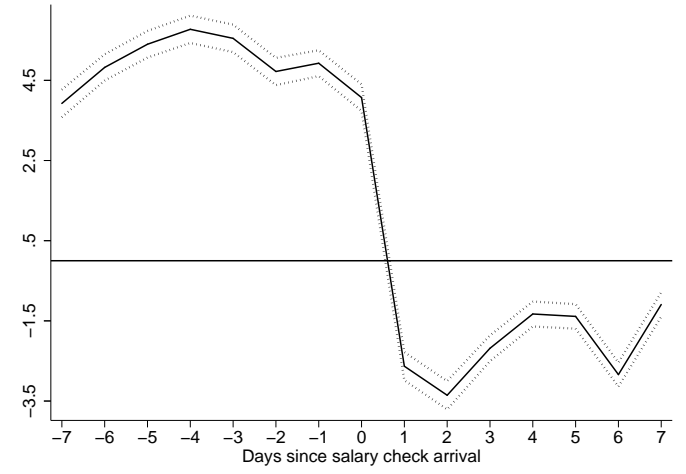

Regular Income Low Liquidity

능

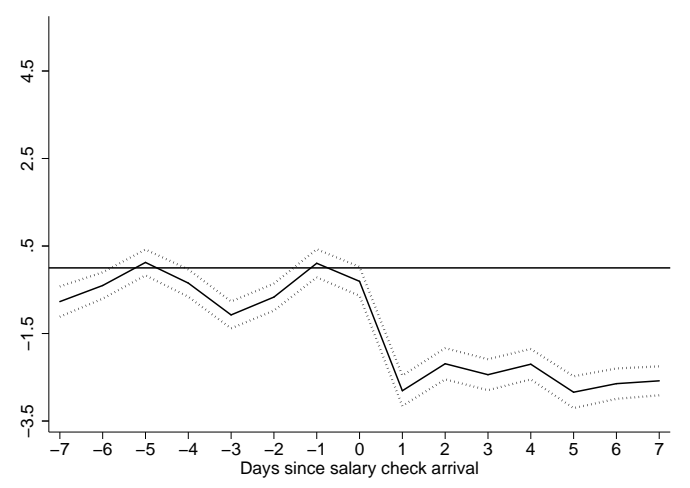

Irregular Income Low Liquidity

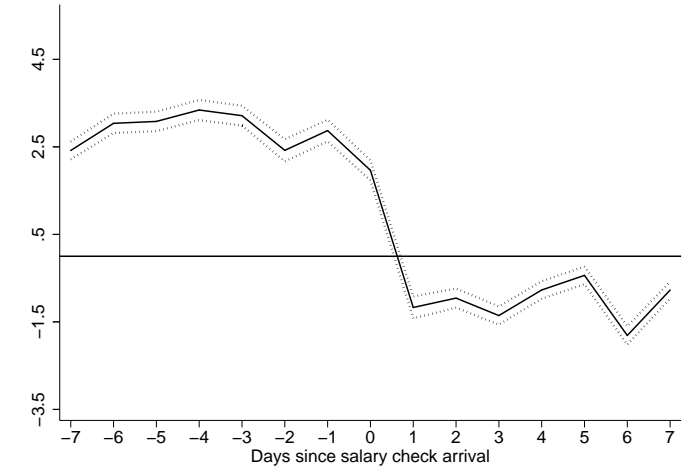

Regular Income Medium Liquidity

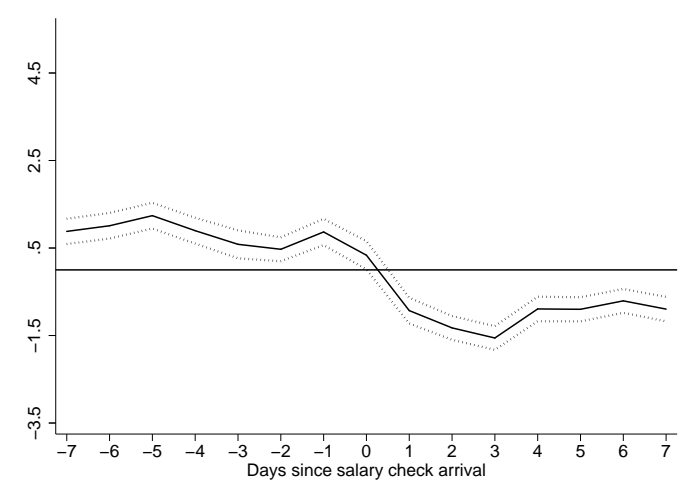

Irregular Income Medium Liquidity

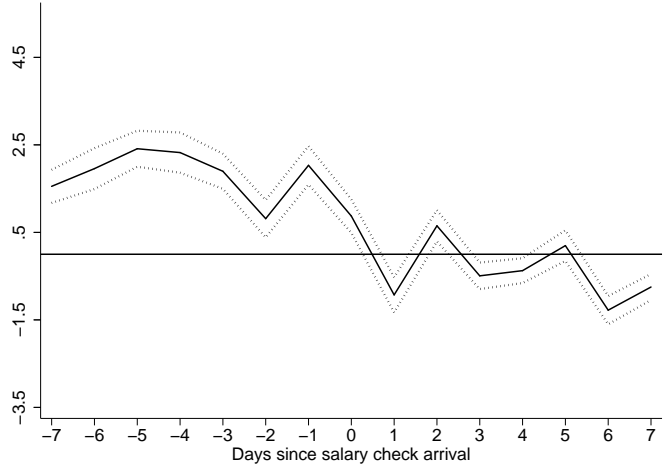

Regular Income High Liquidity

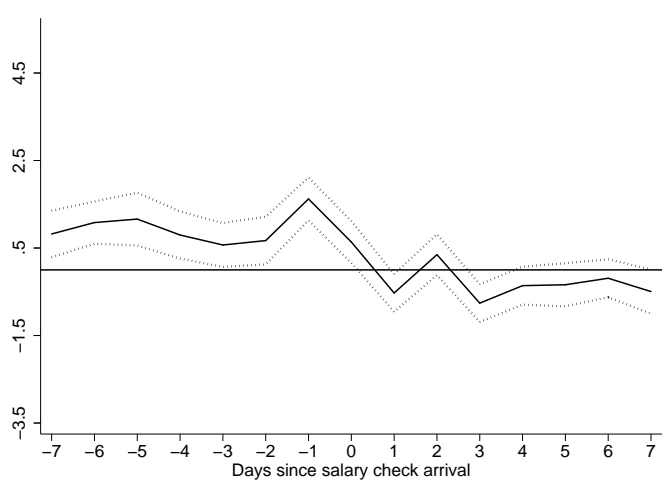

Irregular Income High Liquidity

Figure 19: The Effects of Salary Payments on Overdraft Limits by Terciles of Consumption Days From Current Liquidity 


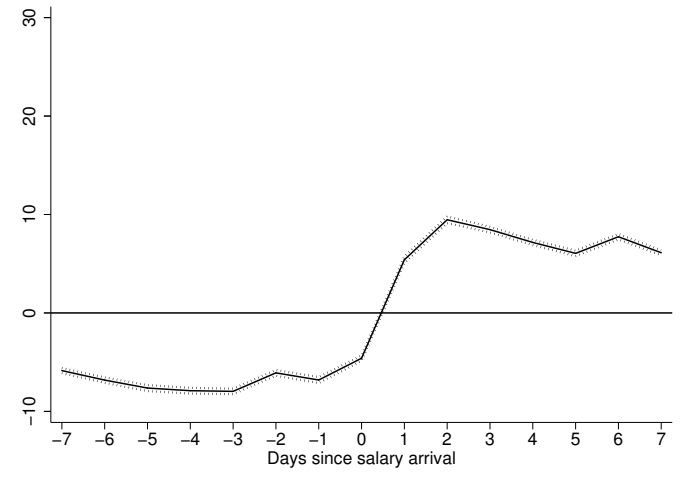

Regular Income Low Liquidity

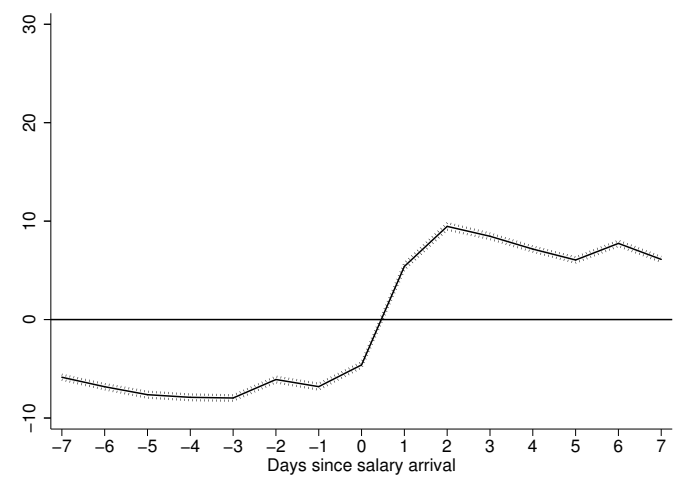

Salary Low Liquidity

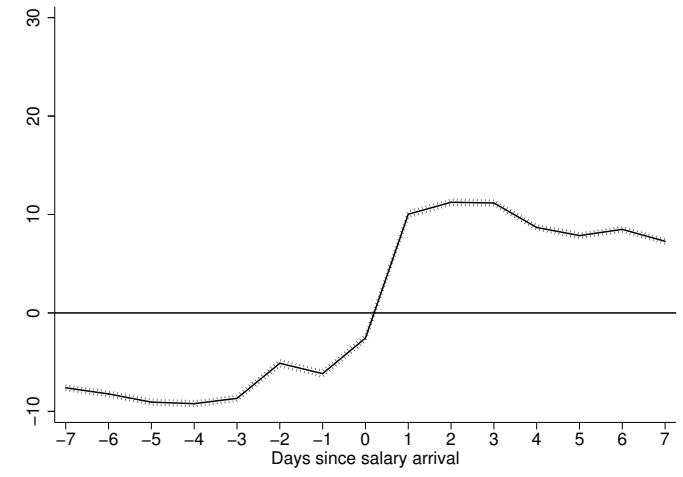

Regular Income Medium Liquidity

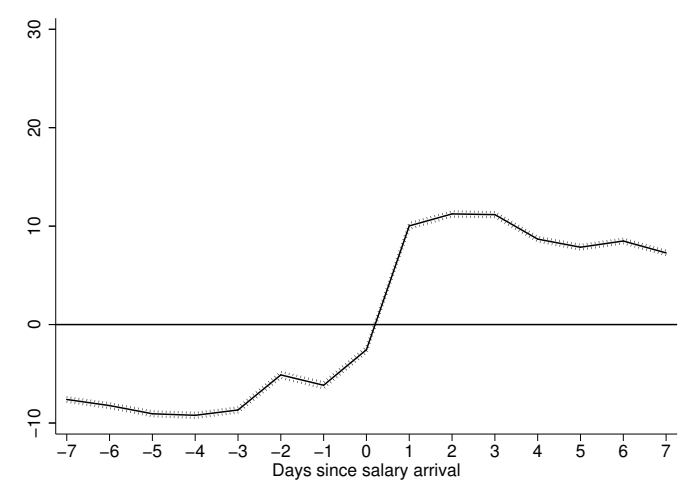

Salary Medium Liquidity

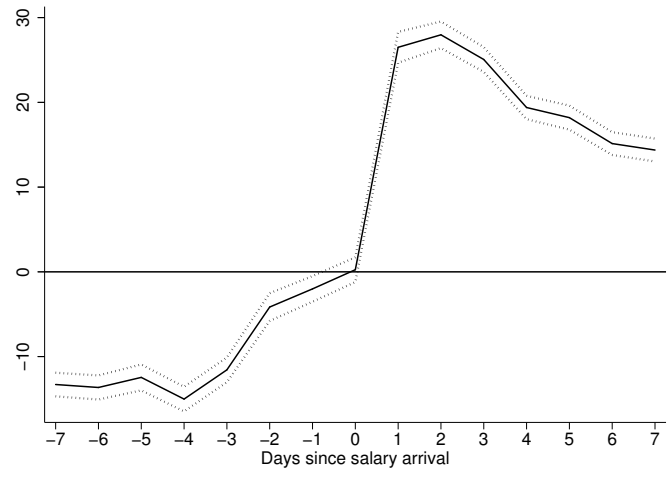

Regular Income High Liquidity

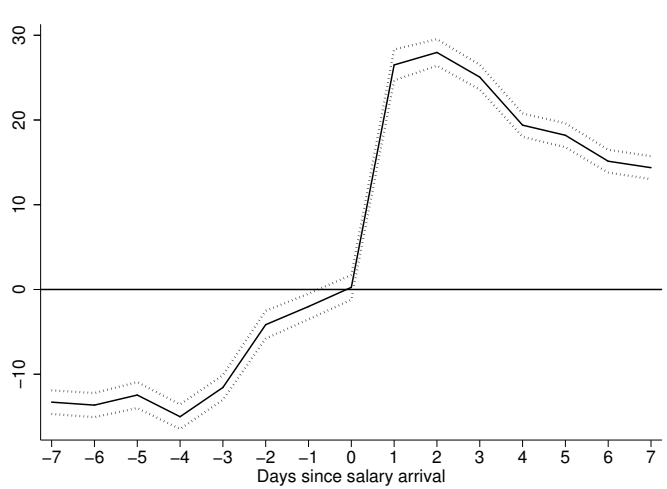

Salary High Liquidity

Figure 20: The Effects of Regular Income and Salary Arrival on Cash minus Credit Balances by Terciles of Consumption Days From Current Liquidity 